\title{
Democracy, Free Elections and Independent Candidates: Critical Remarks On The Jurisprudence Of The European Court Of Human Rights
}

\section{H. Burak Gemalmaz}

\begin{abstract}
In order to bypass the $10 \%$ electoral threshold, a significant number of independent candidates stood for election in 2007 parliamentary elections in Turkey. Having occurred, these independent candidates came upon deprivation of particular rights that political parties enjoy: The right to propaganda on state-run media and being included in the ballots set up in the customs. Taking into consideration of the fact that Turkey is a state party to the European Convention on Human Rights and its Protocol No.1 which provides for the right to free elections in Article 3, these two legal issues require a close examination in terms of supranational human rights law. For this purpose, this article shall address the judgments and admissibility decisions of the European Court of Human Rights (ECtHR) in Oran Case (App. Nos. 28881/07 \& 37920/07, Judgment of 15 April 2014) and Timurhan Case (App. No.28882/07, Admissibility Decision of 16 December 2014) concerning the relationship between individual candidates and free elections. To deal with the issue comprehensively, the correlation among democracy, human rights and good governance shall be analyzed within a framework which is composed of the concept, place and function of the right to political participation as recognized in international human rights law.
\end{abstract}

\section{Keywords}

Elections • ECHR • Independent candidates • Democracy • Good governance • Political participation • Human rights • Margin of appreciation $\bullet$ Positive obligations

\section{Demokrasi, Serbest Seçimler ve Bağımsız Adaylar: Avrupa İnsan Hakları Mahkemesinin Kararları Üzerine} Eleştirel Değerlendirmeler

Öz

Türkiye'de 2007 yılında gerçekleşen milletvekili seçimlerine 10\%'luk seçim barajını delme amacıyla çok sayıda bağımsız aday katılmıştır. Ancak yürürlükte olan mevzuata göre, bağımsız adaylar, başta kamu televizyon kanallarında propaganda yapabilme hakkı ile gümrüklerde verilen oyları elde etme hakkı (gümrüklerde kurulan sandıklarda kullanılan oy pusulalarında yer alma) olmak üzere siyasi partilerin yararlandığı belirli haklardan yararlanamamaktadır. Bu iki hukuki meselenin Avrupa İnsan Hakları Sözleşmesinin serbest seçim hakkını öngören 1 no'lu Protokolü’nün 3. Maddesinde kapsamında ulusalüstü insan hakları hukuku açısından incelenmesi gerekmektedir. Bu amaç doğrultusunda bu makalede AiHM'nin Oran (App. Nos. 28881/07 \& 37920/07, Judgment of 15 April 2014) ve Timurhan (App. No.28882/07, Admissibility Decision of 16 December 2014) başvurularında vermiş olduğu kararlar ele alınacaktır. Meselenin kapsamlı bir şekilde ele alınabilmesi için demokrasi, insan hakları ve iyi yönetim arasındaki korelasyon, ulusalüstü insan hakları hukukunda tanınan siyasi katılma hakkı kavramını, söz konusu hakkın bu alandaki yerini ve işlevini içeren bir çerçevede tahlil edilecektir.

\section{Anahtar Kelimeler}

Serbest seçim • AïHS • Bağımsız aday • Demokrasi • İyi yönetişim • Siyasal katılma • İnsan hakları • Takdir marjı • Pozitif yükümlülükler

\footnotetext{
Correspondence to: H. Burak Gemalmaz (Assoc. Prof. Dr.), Istanbul University, Faculty of Law, Department of General Public Law, Istanbul, Turkey: Email: haydar.gemalmaz@istanbul.edu.tr

To cite this article: Gemalmaz, H. Burak; "Democracy, Free Elections and Independent Candidates: Critical Remarks On The Jurisprudence Of The European Court Of Human Rights", İstanbul Hukuk Mecmuası, 76/1, 2018, 9-63.

** The author would like to thank to Prof. Dr. Mehmet Semih Gemalmaz for his contributions on the preparation of this article. In the "Oran v. Turkey" and "Timurhan v. Turkey" cases examined below, the Applicants were represented by Prof. Dr. Semih Gemalmaz before the European Court of Human Rights.
} 


\section{Introduction: Independent Candidates in 2007 Turkish Parliamentary Elections and Judgments of the European Court of Human Rights}

In April 2007 Turkey was in the process of a presidential election, which failed in early May 2007. Then followed a political crisis, due to the judgment of the Turkish Constitutional Court on the process of the presidential election. On 1 May 2007, the Constitutional Court annulled the first round of the presidential election on the grounds that a quorum of two-thirds of the membership of the Grand National Assembly of Turkey (GNAT) was necessary in the first round of voting. ${ }^{1}$ It was in that context that the GNAT decided to bring forward the date of the next parliamentary elections to 22 July 2007, which would normally have been held on 4 November 2007 . $^{2}$

In addition to political crises, $10 \%$ of the electoral threshold was upheld by the Second Section of the European Court of Human Rights on 30 January 2007³, just before the 2007 elections.

A combination of political crises and the ECtHR's legitimatization of $10 \%$ of the electoral threshold lead to the creation of unique political movements which have not been observed in Turkish electoral campaigns before. To avoid the negative effects of $10 \%$ of the electoral threshold, a significant number of independent candidates stood for the elections. ${ }^{4}$ Since the 1950's, it was the first time that such a situation had occured in the general elections held in Turkey. In fact, the European Court itself is well aware of the reasons which led to such an unusual development. ${ }^{5}$

It is important to note that the increase in the number of independent candidates cannot only be explained by the existence of the electoral threshold of $10 \%$ which was applicable in the 2007 parliamentary elections. In addition to this aforementioned factor, a considerable majority of the population criticized the performance of the political parties in power or in opposition. Consequently, a powerful public demand pushed the emergence of the "independent candidates phenomenon".

Against this background, the Supreme Election Council decided in accordance with the provisions of Article 94/2 of the "Law on the Basic Provisions of the Elections and Electors Registers" (Law No.298, 26 April 1961) (hereafter cited as, "Election Law") that the polling started on 25 June 2007 at the customs. The aim of this process was to provide political participation of Turkish citizens living in foreign countries. ${ }^{6}$

\footnotetext{
Turkish Constitutional Court, E. 2007/45, K.2007/54, 1 May 2007.

2 Detailed analyses of 2007 Turkish Parliamentary elections can be found in Early Parliamentary Elections 22 July 2007, OSCE/ODIHR Election Assessment Mission Report, Warsaw, 22 November 2007.

Yumak and Sadakv. Turkey, App. No. 10226/03, Second Section Judgment of 30 January 2007. On 08 July 2008, the Grand Chamber of the ECtHR finally delivered its judgment concerning $10 \%$ national electoral threshold and found that said threshold did not violate Article 3 of Protocol No. 1 (Yumak and Sadak v. Turkey, App. No.10226/03, Grand Chamber Judgment of 08 July 2008).

${ }^{4}$ Also see, Sinan Alkin, "Underrepresentative Democracy: Why Turkey Should Abandon Europe's Highest Electoral Threshold”, Washington University Global Studies Law Review, Volume 10, Issue 2, 2011, pp.347-369, 356.

Yumak and Sadak v. Turkey, App. No.10226/03, Grand Chamber Judgment of 08 July 2008, paras.22-26, especially paras. 23 and 25.

6 The Supreme Election Council Decision No.282 of 27 May 2007.
} 
According to Article 94/2 of the Election Law as amended by Article 24 of the Law No.3270 of 28 March 1986 ${ }^{7}$, the ballots given at the customs shall be added to the ballots of political parties. The independent candidates cannot enjoy the ballots given in customs.

Article 24 of the Law No.3270 was brought before the Constitutional Court by the main opposition political party at the time with a claim, inter alia, that the said regulation was contrary to the Constitution since the norm only allowed to vote for the political parties, but not to vote for independent candidates.

In its judgment, the Turkish Constitutional Court rejected the claim of unconstitutionality of Article 24 of the Law No.3270 and consequently held that Article 94/2 of the Election Law as amended by Article 24 of the Law No.3270 did not violate the constitutional provisions. ${ }^{8}$ The Constitutional Court observed that "this norm provided only to vote for the political parties and it was the first time that by the introduction of said rule in the election law, the opportunity to vote for independent candidates was repealed". 9 According to the Constitutional Court, the fixation of the period as "more than 6 months" staying abroad was in order to avoid disturbance of the election order. Furthermore, with regard to the electors living abroad, considering the difficulties in voting for a certain election region determined earlier, it was considered appropriate that such electors could vote in a manner which would have an effect only on the total votes received by the political parties. ${ }^{10}$

In view of the Constitutional Court, in such a system, since the impossibility to vote for independent candidates was not as important as depriving the electors living abroad from their right to elect, it was necessary to accept that the privilege provided on the subject matter had a rightful basis and was not contrary to the principle of equality. Since no distinction was provided among the political parties in the distribution of the votes, it was not possible to say that the new system resulted in an inequality among the political parties. ${ }^{11}$

Article 94/2 of the Election Law (No.298) as amended by Article 24 of the Law No.3270 provided that electors who were not registered in the Electors Registers and have been living abroad for a period of more than 6 months are permitted to vote at the customs while entering or leaving the country within a period starting from 70 days before the election date and until $05.00 \mathrm{pm}$ of the election date.

8 The Constitutional Court judgment of 22/05/1987, E.1986/17, K.1987/11, Anayasa Mahkemesi Kararlar Dergisi (Journal of Constitutional Court Decisions), No.23, pp.229-230. It has to be underlined that the Constitutional Court's judgment of 22 May 1987 which dismissed the claim of unconstitutionality was given by just a minor majority, i.e. 5 votes against and 6 votes in favor.

9 In Turkish "Düzenlemenin sonraki bölümleri yalnızca seçime katılan siyasi partilere oy verilebileceğini öngörmekte, seçim yöntemini açıklamaktadır. Seçim hukukumuza ilk kez giren bu kuralla tercih oyu kullanmak ve bağımsızlara oy vermek olanakları kaldırılmıştır."

10 The Constitutional Court's decision in Turkish: "Yurtdışında kalma süresinin 6 aydan fazla tutulması, 6 ay ve daha az süreli giriş çıkışlarda seçim düzenini bozacak kargaşalığı önlemek içindir. Ayrıca, yurtdışındaki seçmenlerin önceden belirlenmiş bir seçim çevresi için oy kullanmalarının güçlüğü gözetilerek yalnızca siyasi partilerin aldıkları toplam oy yönünden sonuç doğuracak biçimde oy kullanmaları uygun bulunmuştur."

11 The Constitutional Court's decision in Turkish: "Böyle bir sistemde bağımsız adaylara oy verememek yurtdışında ikamet eden vatandaşların seçme hakkından yoksun bırakılmalarına neden olacak önemde bulunmadığından bu konuda getirilen ayrıcalığın haklı bir nedene dayandığının ve eşitlik ilkesine aykırı olmadığının kabulü gerekir. Oyların dağılımında siyasi partiler arasında bir ayırım yapılmadığından, yeni sistemin bu konuda siyasi partiler arasında eşitsizliğe neden olduğu söylenemez". 
In the Oran Case, the Applicant, a well-known academician in Turkish daily politics, stood for election in the parliamentary election which was held on 22 July 2007 as an independent candidate. As an independent candidate, the applicant could not have benefited from the ballots used in the customs by the people who were/are entitled to vote, while political parties could enjoy this privilege.

The Applicant applied to the Supreme Election Council (SEC) and claimed that the exclusion of the names of independent candidates in the ballots used at the custom polling stations were incompatible with Article 67 of the Constitution and Article 3 of Protocol No. 1 to the European Convention on Human Rights, as well as relevant provisions of the International Covenant on Civil and Political Rights and the Universal Declaration of Human Rights. The Applicant also urged the SEC that, in accordance with amended Article 90/fine of the Constitution, the SEC should give priority to aforementioned provisions of international human rights conventions, since the domestic legislation in question and the acts/decisions of the SEC based on that legislation were in contradiction with the said international norms. ${ }^{12}$ The SEC, in its response, dated 4 July 2007, after quoting Article 94/II(a) of Law No.298, stated that to include independent candidates into the ballots which shall be used at the custom polling stations requires new legislation. ${ }^{13}$

Moreover, in the Oran Case, the Applicant was not allowed to use the state-run media (Turkish Radio and Television/TRT) for political propaganda. Only political parties were/are allowed to use the state-run media (TRT) in accordance with the Turkish domestic legislation. Article 52/I of the Election Law provided that political parties participating in elections could campaign on national/state run media (radio and televisions of TRT); however, independent candidates who were/are not affiliated to a political party did/does not have the same right.

The SEC decided that “... (c) in the 'election period' which started from 04 May 2007, radio and television enterprises, except the political parties' speeches broadcasted in accordance with Article 52 of the Election Law, shall not broadcast propaganda of a particular political party and (d) shall not broadcast advertisements of political parties and candidates." 14

Pursuant to the SEC's decision of 26 June 2007 (Decision No.600) in accordance with Articles 52-55 of the Election Law, the order and schedule of the propaganda speeches which would be made by political parties at the TRT between 15 July 2007

\footnotetext{
12 It is very recently, the SEC has adopted this view with regard to 2017 Referendum in Turkey (The Supreme Election Council Decision No.560 of 16 April 2017). (http://www.ysk.gov.tr/ysk/content/conn/YSKUCM/path/Contribution\%20Folders/Kararlar/2017-560.pdf).

13 Oran v. Turkey, App. Nos. 28881/07 \& 37920/07, Judgment of 15 April 2014, paras.8-11.

14 Decision No.224 of 04 May 2007, (Official Gazette, 04 May 2007, no.26512).
} 
and 21 July 2007 was determined on 10 July 2007. ${ }^{15}$ The SEC's decision of 26 June 2007 and consequent action of 10 July 2007 on the determination of the order and schedule of the political parties' propaganda speeches at the TRT were final. ${ }^{16}$

In the Timurhan Case, the applicant is a Turkish citizen who lives in USA. Although she had been in Turkey between 24 May 2007 and 03 July 2007, she had neither opportunity to vote for independent candidates nor to learn the names of the individual candidates standing for the general election who were listed under a particular political party's candidate list. Therefore, the applicant was not able to give her vote to an independent candidate. ${ }^{17}$

The decisions of the European Court of Human Rights (ECtHR or European Court):

Both in the Application No.28881/07 (Oran Case) and the Application No. 28882/07 (Timurhan Case) cases concerning custom ballots, the applicants claimed the following violations:

(i) Invoking P1-3, the Applicant in the Oran case claimed that he was deprived from enjoying the ballots given at the customs as a result of the Supreme Election Council's decision No.282 of 27 May 2007 based on amended (by Law No.3270) Article 94/2 of the Election Law, the provision which was found compatible with the Constitution by the Turkish Constitutional Court in its judgment of 22 May 1987. Similarly, the Applicant in the Timurhan case alleged that her inability to vote for independent candidate amounts to an infringement of her electoral rights enshrined in P1-3.

(ii) As the provisions of Election Law create two different candidate categories between independent candidates and affiliated candidates (to political parties), this division amounts to discrimination within the meaning of Article 14 in conjunction with P1-3.

(iii) Since there is no domestic remedy against the decisions of the SEC, the Applicants claimed that their right to have an effective domestic remedy under Article 13 of the Convention has been violated.

In the Application No. 37920/07 (Oran Case) concerning prohibition of political propaganda in State run media by the independent candidates, the Applicant complained of the fact that independent candidates, unlike political parties, were barred by law from campaigning and political propaganda on state run radio and television. Therefore, invoking P1-3 in conjunction with Article 14 of the Convention and invoking Article 10 of the Convention, the Applicant claimed that he was deprived of making political propaganda and campaign in the state-run media, namely official radio and television channels of the TRT, while political parties could do so.

The ECtHR joined Application No.28881/07 and Application No. 37920/07 in view of their similarity and delivered one judgment concerning both applications made by the Baskın Oran. On 15 April 2014, the Second Section of the European Court rejected both

\footnotetext{
15 Decision No.600 of 26 June 2007 (Official Gazette, 27 June 2007, no.26565).

16 Oran v. Turkey, App. Nos. 28881/07 \& 37920/07, Judgment of 15 April 2014, paras.12-16.

17 App. No.28882/07, Admissibility Decision of 16 December 2014.
} 
applications by majority. Three judges appended their separate opinions (See, Separate opinion of Sajo, Keller and Lemmens attached to the judgment of the Second Section). ${ }^{18}$

On 16 December 2014, the Court delivered its admissibility decision in Timurhan case andalso decided that the allegations raised by the applicant (inability to vote for an independent candidate in customs poll) were manifestly ill-founded. ${ }^{19}$

The purpose of the article is to examine the judgment in Oran Case (App. Nos. 28881/07 \& 37920/07, Judgment of 15 April 2014) and admissibility decision in Timurhan Case (App. No.28882/07, Admissibility Decision of 16 December 2014) of the European Court of Human Rights (ECtHR) concerning the relationship between individual candidates and free elections.

In order to shed some light on the legal and conceptual grounds of the subject-matter, firstly, democracy, human rights and good governance will be analyzed and then a general framework will be drawn with respect to the concept, place and function of the right to political participation as recognized in international human rights law.

\section{Democracy, Human Rights and Right To Political Participation}

\section{A. Democracy, human rights and good governance connection}

Human rights, democracy, the rule of law and good governance, (and development) are accepted and considered as interdependent concepts/principles. ${ }^{20}$ These principles are declared as international commitments:

\footnotetext{
Oran v. Turkey, App. Nos. 28881/07 \& 37920/07, Judgment of 15 April 2014.

19 Timurhan v. Turkey, App. No.28882/07, Admissibility Decision of 16 December 2014.
}

20 Thomas M. Franck, Fairness in International Law and Institutions, Oxford - New York, 1997, pp.83-139, especially pp.109-120 ("Chapter 4. Fairness to Persons: The Democratic Entitlement”); Henry J. Steiner/Philip Alston, International Human Rights in Context: Law, Politics, Morals, Oxford - New York, 2000 ( $2^{\text {nd }}$ ed.), pp.888-890; Manfred Nowak, U.N. Covenant on Civil and Political Rights: CCPR Commentary, Germany, 2005 ( $2^{\text {nd }}$ revised edition), pp.564-565; Thomas M. Franck, "The Emerging Right to Democratic Governance", American Journal of International Law, Vol.86, No.1, January 1992, pp.46-91; Gregory H. Fox, “The Right to Political Participation in International Law", Yale Journal of International Law, Vol.17, No.2, 1992, pp.539-607; James Crawford, "Democracy and International Law", British Yearbook of International Law, Vol.64, 1993, pp.113-133; Christina M. Cerna, "Universal Democracy: An International Legal Right or the Pipe Dream of the West?", New York University Journal of International Law and Politics, Vol.27, No.2, 1995, p.289-329; Reginald Ezetah, "The Right to Democracy: A Qualitative Inquiry", Brooklyn Journal of International Law, Vol.22, No.3, 1997, pp.495-534; Roland Rich, "Bringing Democracy into International Law", Journal of Democracy, Vol.12, No.3, July 2001, pp.20-34; Richard Burchill, "The Role of Democracy in the Protection of Human Rights: Lessons From the European and Inter-American Human Rights Systems", Human Rights and Diversity: Area Studies Revisited, (edited by David P. Forsythe and Patrice C. McMahon), Lincoln and London, 2003, pp.137-156, pp.137-138; John O. McGinnis/Ilya Somin, "Democracy and International Human Rights Law", Notre Dame Law Review, Vol.84, No.4, 2009, pp.1739-1798; Cecile Vandewoude, "The Rise of Self-Determination Versus the Rise of Democracy", Goettingen Journal of International Law, Vol.2, No.3, 2010, pp.981-996, pp.988-994; Susan Marks, "What Has Become of the Emerging Right to Democratic Governance?", European Journal of International Law, Vol.22, No.2, 2011, pp.507-524; Christina Binder, “Anything New Since the End of the Cold War? Or International Law Goes Domestic: International Electoral Standards and Their Legitimacy", Anuario Espanol de Derecho Internacional, Vol.27, 2011, pp.435-463; Samantha Besson, "The human right to democracy - a moral defence with a legal nuance", Venice Commission, Definition and Development of Human Rights and Popular Sovereignty in Europe, Science and technique of democracy, No.49, Strasbourg Cedex, December 2011, pp.47-75, especially pp.69-74; Gregory H. Fox, "Democracy, Right to, International Protection", Max Planck Encyclopedia of Public International Law, Max Planck Institute for Comparative Public Law and International Law, 2011, pp.1-13, paras.1-37 (<www.mpepil.com>.); Matthew Saul, "The Search for an International Legal Concept of Democracy: Lessons from the Post-Conflict Reconstruction of Sierra Leone", Melbourne Journal of International Law, Vol.12, 2012, pp.1-29, especially pp.1-10; Jack Donnelly, "Human Rights, Democracy and Development", Human Rights Quarterly, Vol.21, No.3, August 1999, pp.608-632. 
For example, the "Proclamation of Teheran"21 which was adopted at the Teheran Conference convened by the United Nations (UN) in 1968 emphasized that "since human rights and fundamental freedoms are indivisible, the full realization of civil and political rights without the enjoyment of economic, social and cultural rights is impossible."

The following step was taken at the World Conference on Human Rights held in Vienna in 1993. The "Vienna Declaration and Programme of Action"22 of 25 June 1993, which went further than the "Proclamation of Teheran" of 1968, clearly established a link between democracy, development, rule of law and respect for human rights (Section I, para. 8). More recently the "United Nations Millennium Declaration" 23 of 8 September 2000 reaffirmed the same commitment.

At a meeting in Copenhagen in June 1990, members of the Organization for Security and Co-operation in Europe (formerly CSCE, Conference on Security and Cooperation in Europe) adopted "Copenhagen Declaration" in which they affirmed that "democracy is an inherent element of the rule of law" and recognized "the importance of pluralism with regard to political organizations." 24 The "Charter of Paris for a New Europe" 25 of 21 November 1990, under the chapter on Human Rights, Democracy and Rule of Law, states the following: "We undertake to build, consolidate and strengthen democracy as the only system of government of our nations... Democratic government is based on the will of the people, expressed regularly through free and fair elections. Democracy has as its foundation respect for human rights and the rule of law..." The signatories also stated the following: "We affirm that, without discrimination, every individual has the right to: ... to participate in free and fair elections." In October 1991 the member states of the CSCE adopted the Document of the Moscow Meeting of the Conference on Human Dimensions of the CSCE". The Document reaffirms "that issues relating to human rights, fundamental freedoms, democracy and the rule of law are of international concern, as respect for these rights and freedoms constitutes one of the foundations of the international order." 26

21 The "Proclamation of Teheran" of 13 May 1968, see, United Nations, Human Rights: A Compilation of International Instruments, Volume 1 (First Part), New York, 1994, pp.51-54.

22 The "Vienna Declaration and Programme of Action" of 25 June 1993 provides the following: "Democracy, development and respect for human rights and fundamental freedoms are interdependent and mutually reinforcing. Democracy is based on the free expressed will of the people to determine their own political, economic, social and cultural systems and their full participation in all aspects of their lives...", (Section I, para.8).

23 The "United Nations Millennium Declaration" was adopted by the UN General Assembly resolution 55/2 of 8 September 2000. Under the "Section V. Human Rights, Democracy and Good Governance" (para.25) reads as follows: "25. We resolve therefore: - To respect fully and uphold the Universal Declaration of Human Rights; - To strive for the full protection and promotion in all countries of civil, political, economic, and social rights for all; - To strengthen the capacity of all our countries to implement the principles and practices of democracy and respect for human rights, including the minority rights..."

${ }^{24} I L M$, Vol.29, 1990, p.1305. <http://www.osce.org/documents/odihr/1990>. Also see Franck, Fairness in International Law and Institutions, p.114; Fox, "Democracy, Right to, International Protection", para.26.

25 The "Charter of Paris for a New Europe" of 21 November 1990. ILM, Vol.30, 1991, pp.190, 194; HRLJ, Vol.11, Parts 3-4, 1990, pp.379-389.

${ }_{26}$ ILM, Vol.30, 1991, p.1670. Also see, Franck, Fairness in International Law and Institutions, p.116. Fox, "Democracy, Right to, International Protection", para.5. 
The United Nations (UN) General Assembly adopted a resolution on "Enhancing the effectiveness of the principle of periodic and genuine elections" at its 1990 session. ${ }^{27}$ Article 2 of this resolution stresses the member nations' "conviction that periodic and genuine elections are a necessary and indispensable element of sustained efforts to protect the rights and interests of the governed and that, as a matter of practical experience, the right of everyone to take part in the government of his or her country is a crucial factor in the effective enjoyment by all of a wide range of other human rights and fundamental freedoms, embracing political, economic, social and cultural rights." The resolution also declares that "determining the will of the people requires an electoral process that provides an equal opportunity for all citizens to become candidates and put forward their political views, individually and in cooperation with others, as provided in national constitutions and laws" (Article 3 ). ${ }^{28}$

Starting from 1992 the UN General Assembly resolutions on the matter basically focused on the role of the UN is to enforce the practical and procedural aspects ${ }^{29}$ of such a right to electoral democracy. ${ }^{30}$

After the "Vienna Declaration and Programme of Action" of 25 June 1993, at its 1999 session, the UN Commission on Human Rights adopted the resolution of "Promotion of the right to democracy"31, which the effort to delete the term "right to democracy" was defeated by only a minor majority (by 28 votes to 12, with 13 abstentions), was important as it refers to the right. However, except its title, the "right to democracy" was not repeated in the text itself. ${ }^{32}$

Coming to more recent documents, the "Universal Declaration on Democracy"33 which was adopted by the Interparliamentary Council (i.e. a body of the

27 The UN General Assembly resolution 45/150 on "Enhancing the effectiveness of the principle of periodic and genuine elections" of 18 December 1990.

28 Franck, Fairness in International Law and Institutions, p.111; Fox, "Democracy, Right to, International Protection", para.26.

29 Rich, p.26; Fox, "Democracy, Right to, International Protection", para.8.

30 UNGA Res. 47/138, 18 December 1992; UNGA Res. 48/131, 20 December 1993; UNGA Res. 49/30, 7 December 1994; UNGA Res. 49/190, 23 December 1994; UNGA Res. 50/133, 20 December 1995; UNGA Res. 51/31, 6 December 1996; UNGA Res. 52/18, 15 January 1998; UNGA Res. 53/31, 23 November 1998; UNGA Res. 54/36, 29 November 1999; UNGA Res. 55/44, 27 November 2000; UNGA Res. 56/96, 14 December 2001. See, Jan Wouters/Bart De Meester/Cedric Ryngaert, Democracy and International Law, Leuven Interdisciplinary Research Group on International Agreements and Development, Working Paper No. 5 - June 2004, pp.1-49, p.9 (<https://www.law.kuleuven.be/iir/nl/onderzoek/wp/ WPLirg5.pdf > accessed on August 2017.); Jean D'Aspremont, "Legitimacy of Governments in the Age of Democracy", International Law and Politics, Vol.38, 2006, pp.877-917, pp.887-888.

31 The "Promotion of the right to democracy" was adopted by the UN Commission on Human Rights resolution 1999/57.

32 Rich, p.24; Fox, "Democracy, Right to, International Protection", para.4.

33 The "Universal Declaration on Democracy" was adopted without voting by the Interparliamentary Council at its $161^{\text {st }}$ session, Cairo, 16 September 1997. For the text see, Netherlands Quarterly of Human Rights, Vol.18, No.1, March 2000, pp.127-130. Article 1 of this Declaration provides that, "Democracy is a universally recognised ideal as well as a goal, which is based on common values shared by peoples throughout the world community irrespective of cultural, political, social, and economic differences. It is thus a basic right of citizenship to be exercised under conditions of freedom, equality, transparency and responsibility, with due respect for plurality of views, and in the interest of polity." But Article 2 added that democracy "is thus a constantly perfected and always perfectible state or condition whose progress will depend upon a variety of political, social, economic and cultural factors." Nevertheless, Article 12 of the Declaration reaffirms the following: "The key element in the exercise of democracy is the holding of free and fair elections at regular intervals enabling the people's will to be expressed. These elections must be held on the basis of universal, equal and secret suffrage so that all voters can choose their representatives in conditions of equality, openness and transparency that stimulate political competition. To that end, civil and political rights are essential, and more particularly among them, the rights to vote and to be elected, the rights to freedom of expression and assembly, access to information and the right to organise political parties and carry out political activities. Party organisation, activities, finances, funding and ethics must be properly regulated in an impartial manner in order to ensure the integrity of the democratic processes." 
Interparliamentary Union, an organization of parliaments of sovereign States, established in 1889) on 16 September 1997, and the 'Final Warsaw Declaration: Toward a Community of Democracies"34 of 27 June 2000, democracy is not stated as a real right but rather as an ideal and aim. ${ }^{35}$

At the regional level, the "Charter of the Organization of American States"36 (the Charter of the OAS) of 30 April 1948 is significant due to the fact that it proclaims democracy as an internationally guaranteed right (Article 3/d). Also in Article 2/b of the Charter of the OAS promotion and consolidation of representative democracy has been declared as one of the essential purposes of the OAS.

Despite such strong terms concerning the importance of democracy by international bodies, it is not clear whether these statements are lex lata, de lege ferenda or mere political aspirations. ${ }^{37}$ The relativity and generality of the concept of democracy has also been considered as one of the difficulties in a meaningful implementation of the concept as part of international law. ${ }^{38}$

Moreover, from the perspective of international law there is no one and certain definition of democracy as the UN General Assembly consistently affirms "the right of peoples to determine methods and to establish institutions regarding electoral processes", (UN resolution of 16 December 2005). ${ }^{39}$ Also a consensus seems that there is no single model of democracy, which has been reaffirmed on several occasions by the UN General Assembly. ${ }^{40}$

However, it appears that there is an international consensus that the legitimacy of governments depends on the consent of the governed, which constitutes an essential element and precondition of democracy. Furthermore, there is a strong and widespread consensus and acceptance that the right to political participation constitutes one of the fundamental human rights as has already been recognized by various international and regional human rights instruments. As stated by Prof. Nowak, "the main components

34 The "Warsaw Declaration: Towards a Community of Democracies", 27 June 2000, ILM, Vol.39, No.6 (Nov., 2000), pp.1306-1308. In this Declaration democracy is described as "a basic right of citizenship", (Article 1).

35 Wouters/ Meester/Ryngaert, p.16; D'Aspremont, p.893.

36 The "Charter of the Organization of American States" (Charter of the OAS) was adopted by the Ninth International Conference of American States, Bogota, Colombia, on 30 April 1948, and entered into force on 13 December 1951. See, Organization of American States, Basic Documents Pertaining to Human Rights in the Inter-American System (Updated to May 2001), OAS, General Secretariat, Washington, D.C., 2001, pp.194-229. Also see, Thomas Buergenthal/Robert Norris/Dinah Shelton, Protecting Human Rights in the Americas, Germany, 1990 (3rd ed.), pp.475-487.

37 Fox, "Democracy, Right to, International Protection", para.5; Saul, p.5.

38 Vandewoude, p.990; Fox, "Democracy, Right to, International Protection”, para.35 (“...Such definitions are so broad as to become almost useless as standards of measurement capable of meaningfully evaluating State conduct. Both conceptions of democracy have substantial defects that have limited their ascendance into law."); Marks, "What Has Become of the Emerging Right to Democratic Governance?", p.511; Saul, p.5.

39 UN General Assembly resolution 60/164 of 16 December 2005, (GAOR 60 $0^{\text {th }}$ Session Supp 49, Vol.1, p.39). See, Fox, "Democracy, Right to, International Protection", para.7.

40 For example see, UN General Assembly resolution 55/96, 28 February 2001, preambular para.8; resolution 60/253, 2 May 2006, preambular para.10; resolution 61/226, 14 March 2007, preambular para.7; resolution 62/7, 13 December 2007, preambular para.7. See, Vandewoude, p.991, note 47. 
of democracy, i.e., the right of the people to sovereignty, internal self-determination and equal participation in political decision-making processes together with the protection of minorities against the 'tyranny of the majority', are already part of the international law of human rights." 41

\section{B. Right To Political Participation}

Rights to "political participation" 42 , in particular fair and free elections constitute the core of the procedural aspect of the right to democracy. Both international and regional human rights conventions, as well as the jurisprudence of the organs established by these instruments draw a general framework and indicate some applicable standards with regard to procedural dimension of the right to political participation. ${ }^{43}$ The right to participate in governance through free and fair elections requires States to establish a functioning political institution and regulatory framework to protect, maintain, and facilitate those participatory rights. ${ }^{44}$ The right to political participation includes, but does not limited to fair and free elections. ${ }^{45}$

Although some scholars argue against the right to political participation interpreted as a right to democracy, there are also views in favor of the right to political participation need not imply a right to democracy. ${ }^{46}$ Even some scholars go further to suggest that international human rights law standards should not be imposed on democratic states as they have sufficient grounds for an operational democratic regime, but the imposition of such standards might be useful for totalitarian regimes. ${ }^{47}$ If it is so then the question as to how such standards would still be treated as equally applicable international standards to all nations remains unanswered. Beyond that, there is no way to argue the legitimization of legal immunity for the so-called well established democratic countries' numerous breaches of human rights, which were taken before international human rights supervisory bodies due to fact that such violations were not remedied or rectified under domestic law.

\footnotetext{
$41 \quad$ Nowak, p.565.

42 Henry Steiner, "Political Participation as a Human Right", Harvard Human Rights Yearbook, Vol.1, 1988, p.77-134; Franck, "The Emerging Right to Democratic Governance", pp.46-91; Fox, "The Right to Political Participation in International Law", pp.539-607; Crawford, pp.113-133; Cerna, p.289-329; Ezetah, pp.505-507; Henry Steiner, "Two Sides of the Same Coin? Democracy and International Human Rights", Israel Law Review, Vol.41, No.3, Winter 2008, pp.445-476; Vandewoude, pp.988-994; Katharine A. Wagner, "Identifying and Enforcing 'Back-End' Electoral Rights in International Human Rights Law", Michigan Journal of International Law, Vol.132, Fall 2010, pp.165-214; Marks, "What Has Become of the Emerging Right to Democratic Governance?", pp.507-524; Binder, pp.442-462; Besson, pp.4775; Fabienne Peter, "The Human Right to Political Participation", Journal of Ethics \& Social Philosophy, Vol.7, No.2, February 2013, pp.1-16, especially pp.10-14; Ludvig Beckman, "The Right to Democracy and the Human Right to Vote: The Instrumental Argument Rejected", Journal of Human Rights, Vol.13, No.4, 2014, pp.381-394; Alecia Johns, "The Case for Political Candidacy as a Fundamental Human Right", Human Rights Law Review, Vol.16, 2016, pp.29-54.

43 Fox, "The Right to Political Participation in International Law", pp.552-570; Saul, pp.3-4.

44 Wagner, p.168; Fox, "The Right to Political Participation in International Law", p.596.

45 Vandewoude, pp.991-992; Binder, pp.462-463; Beckman, pp.381-394.

46 Marks, "What Has Become of the Emerging Right to Democratic Governance?", pp.511-521; Peter, pp.11-12.

47 See, McGinnis/Somin, pp.1739-1798.
} 
The right to political participation has been recognized in various regional and international "soft" and "hard" human rights instruments. With regard to "soft law" instruments, both regional and international levels, for instance, Article XX of the "American Declaration of the Rights and Duties of Man"48 of 2 May 194849; Article 21/1, 21/3 of the "Universal Declaration of Human Rights"50 (UDHR) of 10 December 194851; The "Declaration on the Elimination of Discrimination against Women" 52 of 7 November 1967 Article 4/a-b ${ }^{53}$ and The Organization of American States' (OAS) instrument of the "Inter-American Democratic Charter"54 of 11 September $2001^{55}$ might be added to the list.

48 The "American Declaration of the Rights and Duties of Man" was adopted by the Ninth International Conference of American States, Bogota, Colombia, on 2 May 1948. Also see, Organization of American States, pp.15-21. Article XX of the "American Declaration of the Rights and Duties of Man reads as follows:

"Every person having legal capacity is entitled to participate in the government of his country, directly or through his representatives, and to take part in popular elections, which shall be by secret ballot, and shall be honest, periodic and free." The American Declaration of the Rights and Duties of Man is unique as it also provides a corresponding duty, i.e. duty to vote, in its Article XXXII, which reads as follows: Article XXXII - It is the duty of every person to vote in the popular elections of the country of which he is a national, when he is legally capable of doing so."

49 Although the American Declaration was considered non-binding when it was adopted in 1948, it would gain the character of an authoritative interpretation of the OAS Charter in the field of human rights (see, Burchill, p. 140). The Inter-American Court on Human Rights (I-ACtHR), in its Advisory Opinion OC-10/89 of 14 July 1989, places the 1948 American Declaration as part of the inter-American human rights system and attributes a legal effect. The I-ACtHR clearly stated: "That the Declaration is not a treaty does not, then, lead to the conclusion that it does not have legal effect, nor that the Court lacks the power to interpret it." (see, I-ACtHR, Advisory Opinion OC-10/89 of 14 July 1989, Series A No.10, "Interpretation of the American Declaration of the Rights and Duties of Man within the Framework of Article 64 of the American Convention on Human Rights", paras.37-38, 47).

50 The "Universal Declaration of Human Rights" was adopted by the UN General Assembly resolution 217 A (III) of 10 December 1948. Article 21/1 and 21/3 provides that

"1. Everyone has the right to take part in the government of his country directly or through freely chosen representatives... 3. The will of the people shall be the basis of the authority of government; this will shall be expressed in periodic and genuine elections which shall be by universal and equal suffrage and shall be held by secret vote or by equivalent free voting procedures."

51 For a full analysis of Article 21, including Preparatory Works, of the UDHR see, Allan Roses, "Article 21", in, The Universal Declaration of Human Rights: A Common Standard of Achievement, Gudmundur Alfredsson and Asbjorn Eide (eds.), The Hague, 1999, pp.431-451. Also see, David Weissbrodt/Connie de la Vega, International Human Rights Law: An Introduction, Philadelphia, 2007, pp.113-115; John P. Humphrey, "Political and Related Rights", in, Human Rights in International Law: Legal and Policy Issues, Theodor Meron (ed.), Oxford, 1984, pp.171-203, pp.191-193.

Moreover, it has been suggested that Article 21 of the UDHR should also read in conjunction with Article 28 of the Declaration which stipulates that "Everyone is entitled to a social and international order in which the rights and freedoms set forth in this Declaration can be fully realized." (see, Ezetah, pp.521-522).

52 The "Declaration on the Elimination of Discrimination against Women" was adopted by the UN General Assembly resolution of 7 November 1967.

53 (Article 4/a-b) of the "Declaration on the Elimination of Discrimination against Women" reads as follows: "Article 4 - All appropriate measures shall be taken to ensure to women on equal terms with men, without any discrimination: (a) The right to vote in all elections and be eligible for election to all publicly elected bodies; (b) The right to vote in all public referenda. (c) (...) Such rights shall be guaranteed by legislation."

54 The "Inter-American Democratic Charter" was adopted by the General Assembly of the Organization of American States on 11 September 2001. Article 3 of the Charter provides that "Essential elements of representative democracy include, inter alia, respect for human rights and fundamental freedoms, access to and the exercise of power in accordance with the rule of law, the holding of periodic, free, and fair elections based on secret balloting and universal suffrage as an expression of the sovereignty of the people, the pluralistic system of political parties and organizations, and the separation of powers and independence of the branches of government."

Other relevant provisions of the "Inter-American Democratic Charter" read as follows: "Democracy is essential for the social, political, and economic development of the peoples of the Americas" (Article 1/II); "The strengthening of political parties and other political organizations is a priority for democracy. Special attention will be paid to the problems associated with the high cost of election campaigns and the establishment of a balanced and transparent system for their financing" (Article 5); "Democracy is indispensable for the effective exercise of fundamental freedoms and human rights in their universality, indivisibility and interdependence, embodied in the respective constitutions of states and in inter-American and international human rights instruments" (Article 7).

55 Sonia Picado, "The Evolution of Democracy and Human Rights in Latin America: A Ten Year Perspective", Human Rights Brief, Vol.11, No.3, 2004, pp.28-31, pp.29-30; Timothy D. Rudy, "A Quick Look at the Inter-American Democratic Charter of the OAS: What is it and is it "legal'?", Syracuse Journal of International Law and Commerce, Vol.33, No.1, 2005, pp.237-248; Weissbrodt/Vega, p.117; Fox, "Democracy, Right to, International Protection”, para.4. 


\section{(1) Right to political participation under the UN human rights systems.}

The ICCPR and Human Rights Committee: In the context of the "hard law" instruments one may first refer to the "International Covenant on Civil and Political Rights" $" 56$ (hereinafter the Covenant or ICCPR) of 19 December 1966. In the ICCPR the principal provision on political rights is regulated under Article 25, in which three fundamental guarantees are recognized: non-discrimination, the right to participate in public affairs, and the right to free elections ${ }^{57}$ Article 25 of the ICCPR reads as follows:

"Article 25 - Every citizen shall have the right and opportunity, without of the any distinctions mentioned in article 2 and without unreasonable restrictions: (a) To take part in the conduct of public affairs, directly or through freely chosen representatives; (b) To vote and to be elected at genuine periodic elections which shall be universal and equal suffrage and shall be held by secret ballot, guaranteeing the free expression of the will of the electors." ${ }^{n 8}$

Other relevant provisions in the ICCPR with respect to participatory rights are as follows: prohibition of discrimination (Article 2/1), right to hold opinions (Article 19), right to peaceful assembly (Article 21), right to freedom of association (Article 22), and right to equality before the law (Article 26). ${ }^{59}$ Moreover Article 27 of the ICCPR on the protection of minority rights is also related to political participatory rights provision. ${ }^{60}$

Article 25 of the ICCPR had also remained nonfunctional for a long time. ${ }^{61}$ Indeed it was not until 1996 that the ICCPR supervisory body, the Human Rights Committee (HRC) dealt with the provision thoroughly. The HRC interpreted the scope of Article 25 of the Covenant in its General Comment No.25 of 12 July 1996 on the right to vote. ${ }^{62}$ The HRC first states that "Article 25 of the Covenant recognizes and protects the right of every citizen to take part in the conduct of public affairs, the right to vote and to be elected and the right to have access to public service" (para.1). According to the HRC, Article 25 protects the rights of "every citizen", and "no distinctions are permitted between citizens in the enjoyment of these rights on the grounds of race, colour, sex, language, religion, political or other opinion, national or social origin, property, birth or other status" (para.3).

56 The ICCPR was adopted by the UN General Assembly resolution 2200 A (XXI) of 16 December 1966, opened for signature on 19 December 1966, and entered into force on 23 March 1976.

57 Nowak, pp.563-596, especially pp.574-584; Weissbrodt/Vega, pp.113-115; Franck, Fairness in International Law and Institutions, p.110; Fox, "The Right to Political Participation in International Law", p.553.

58 Paragraph (c) of Article 25 is omitted here since it regulates right to equality in access to public service.

59 Nowak, pp.27-57 (Article 2/1), pp.437-467 (Article 19), pp.481-494 (Article 21), pp.495-512 (Article 22), pp.597-634 (Article 26); Steven Wheatley, "Democracy in International Law: A European Perspective", International \& Comparative Law Quarterly, Vol.51, No.2, April 2002, pp. 235-246; Saul, pp.3-4.

60 Nowak, CCPR Commentary, 2005 ( $2^{\text {nd }}$ ed.), pp.635-667 (Article 27); Weissbrodt/Vega, pp.113-114.

61 Fox, "The Right to Political Participation in International Law", pp.539-607; Steiner, "Democracy and International Human Rights", pp.447-449, 455-460; Besson, pp.50-51.

62 The HRC "General Comment No.25 (57), The right to participate in public affairs, voting rights and the right of equal access to public service", see, Report of the HRC, Vol.1, 13 April 1997, General Assembly Official Records, Fifty-first session, Supplement No. 40 (A/51/40), UN, New York, 1997, Annex V, pp.98-103. 
It is true that the right guaranteed in Article 25 might be subject to some restrictions. According to the HRC, however, the States Parties have no unlimited discretion in imposing restrictions on the use of voting rights. Any conditions that apply to the political participation protected by Article 25 should be based on objective and reasonable criteria (para.4). It is significant to note that according to the $\mathrm{HRC}$, the right of persons to stand for election should not be limited unreasonably by requiring candidates to be members of parties or of specific parties (para.17).

The HRC also clarifies "positive obligations" of States Parties in this context. In the opinion of the HRC freedom of expression, assembly and association are essential conditions for the effective exercise of the right to vote and must be fully protected. Positive measures should be taken to overcome specific difficulties (para.12).

And finally the HRC indicates that any system operating in a State party must be compatible with the rights protected by Article 25 with a view to give full effect to the free expression of the will of the electors. To this end, "the drawing of electoral boundaries and the method of allocating votes should not distort the distribution of voters or discriminate against any group and should not exclude or restrict unreasonably the right of citizens to choose their representatives freely" (para.21).

Furthermore, the HRC in its General Comment No.23 of 8 April 1994 on the minority rights (Article 27$)^{63}$ indicates that whatever the political system selected, governments should adopt measures to ensure the effective participation of members of minority communities in decisions which affect them (para.7).

Since Turkey is a State Party to the ICCPR and ratified the Covenant without any reservation with regard to Article $25^{64}$, it is under international law obligation to establish and maintain a fair electoral system. ${ }^{65}$

Other international instruments: At the international level the following instruments may also be cited: the "Convention on the Political Rights of Women" of 20 December 1952 (Article 1) ${ }^{66}$; the "International Convention on the Elimination

63 The HRC "General Comment No.23 (50), the rights of minorities (Article 27)", see, Report of the HRC, Vol.1, 21 September 1994, General Assembly Official Records, Forty-ninth session, Supplement No. 40 (A/49/40), UN, New York, 1994, Annex V, pp.107-110.

64 For Turkey's ratification of the ICCPR and reservations and reactions to these reservations see, Mehmet Semih Gemalmaz, Ulusalüstü İnsan Hakları Hukukunun Genel Teorisine Giriş (Introduction to General Theory of Supranational Human Rights Law), Cilt 1, Legal Yayınları, Istanbul, 2012 ( $8^{\text {th }}$ ed.), pp.230-234.

65 Ricardo Zimbron, "The Unappreciated Margin: Turkish Electoral Politics Before the European Court of Human Rights", Harvard International Law Journal Online, Vol.49, November 13, 2007, pp.10-20, p.17-18. Zimbron argues that considering the standard laid down by the HRC in para.21 of its General Comment No.25, Turkey's national electoral threshold (10\%) is not compatible with Article 25 of the Covenant, especially when one may take into account of the average for majority of the Council of Europe member States is only $5 \%$.

66 The "Convention on the Political Rights of Women" was adopted by the UN General Assembly resolution of 20 December 1952; opened for signature on 31 March 1953, and entered into force on 7 July 1954. Article 1 of the "Convention on the Political Rights of Women" reads as follows: "Women shall be entitled to vote in all elections on equal terms with men, without any discrimination." 
of All Forms of Racial Discrimination" (CERD) of 7 March 1966 (Article 5/c) ${ }^{67}$; the "Convention on the Elimination of All Forms of Discrimination against Women" (CEDAW) of 1 March 1980 (Article 7) ${ }^{68}$.

\section{(2) Right to political participation under regional human rights systems}

The Inter-American system: Looking at the regional level instruments, the "InterAmerican Convention on Human Rights" ${ }^{69}$ (IACHR) of 22 November 1969, Article $23 / 1$, a-b \& $23 / 2^{70}$ reads as follows:

"Article 23 - Right to Participate in Government: 1. Every citizen shall enjoy the following rights and opportunities: (a) to take part in the conduct of public affairs, directly or through freely chosen representatives; (b) to vote and to be elected in genuine periodic elections, which shall be by universal and equal suffrage and by secret ballot that guarantees the free expression of the will of the voter... 2. The law may regulate the exercise of the rights and opportunities referred to in the preceding paragraph only on the basis of age, nationality, residence, language, education, civil and mental capacity, or sentencing by a competent court in criminal proceedings."’1

In the Preamble of the IACHR, State Parties reaffirmed "their intention to consolidate..., within the framework of democratic institutions, a system of personal liberty and social justice based on respect for the essential rights of man." Moreover, Article 29/c of the IACHR provides that, the Convention provisions shall not preclude "other rights or guarantees that are inherent in the human personality or derived from representative democracy as a form of government" (emphasis added). ${ }^{72}$

67 The "International Convention on the Elimination of All Forms of Racial Discrimination" was adopted and opened for signature by the UN General Assembly resolution of 21 December 1965, and entered into force on 4 January 1969. Article 5/c of the CERD reads as follows: "Article 5-(...) State Parties undertake to prohibit and to eliminate racial discrimination in all its forms and to guarantee the right of everyone (...) the following rights: "(c) Political rights, in particular the right to participate in elections - to vote and to stand for election- on the basis of universal and equal suffrage, to take part in the Government as well as in the conduct of public affairs at any level..."

68 The CEDAW was adopted by the UN General Assembly resolution of 18 December 1979, opened for signature on 1 March 1980, and entered into force on 3 September 1981. Article 7 CEDAW reads as follows: "Article 7 - States Parties shall take all appropriate measures to eliminate discrimination against women in the political and public life of the country and, in particular, shall ensure to women, on equal terms with men, the right: (a) To vote in all elections and public referenda and to be eligible for election to all publicly elected bodies; (b) To participate in the formulation of government policy and the implementation thereof and to hold public office and perform all public functions at all levels of government..."

Right to vote and stand for election provided in Article 7/a of the CEDAW seems to be taken from Article 4/a-b of the Declaration on the Elimination of Discrimination against Women of 7 November 1967.

69 The "American Convention on Human Rights" was adopted and opened for signature on 22 November 1969, and entered into force on 18 July 1978. For the text see, Organization of American States, pp.23-47.

70 Literature on Article 23 of the IACHR: Scott Davidson, The Inter-American Human Rights System, Great Britain, 1997, pp.339-345; Scott Davidson, "The Civil and Political Rights Protected in the Inter-American Human Rights System", in, The Inter-American System of Human Rights, David J. Harris and Stephen Livingstone (eds.), Oxford, 1998, pp.213288, pp.280-284; Burchill, pp.138-145; Amaya Ubeda de Torres, "Political Rights", in, Laurence Burgorgue-Larsen and Amaya Ubeda de Torres, The Inter-American Court of Human Rights: Case Law and Commentary, (translated by Rosalind Greenstein), Oxford - New York, 2011, pp.589-612.

71 Article 23/1, (c) of the IACHR is excluded here as it regulates the right to access to the public service.

72 These commitments were reaffirmed in the "Additional Protocol to the American Convention on Human Rights in the Area of Economic, Social and Cultural Rights" (which is also known as the "Protocol of San Salvador") of 17 November 1988, which was adopted on 17 November 1988, and entered into force on 16 November 1999. In para.2 of the Preamble of the "Protocol of San Salvador", the States Parties reaffirmed their commitment stated in the Preamble para.1 of the IACHR. Furthermore, in para.7 of the Preamble of the "Protocol of San Salvador", signatories further stress the need for "full 
As seen in the wording of Article 23 of the IACHR, although the political rights provided there in are subject to certain limitations, the restriction grounds stipulated in Article $23 / 2$ is exclusive. ${ }^{73}$ It means that no other grounds may be used for limitations.

It is noteworthy that, since the exceptions (rights which shall not be subjected to suspension) recognized in Article 27/2 of the IACHR include Article 23, the guarantees in the latter cannot be suspended or derogated in the circumstances of "states of exceptions/emergencies". ${ }^{74}$

The Inter-American Court of Human Rights (I-ACtHR) in the Case of Yatamav. Nicaragua Judgment of 23 June 2005, dealt with a case concerning alleged violations in municipal elections emanating from an electoral law. Article 82 of the Electoral Act of 2000 (No.331) required each political party to have candidates in at least $80 \%$ of the municipalities (paras.124/24, 221). In this case the I-ACtHR held that the requirement of Electoral Act No. 331 of 2000 constitutes a disproportionate restriction that unduly limited the political participation of the candidates proposed by Yatama for the municipal elections of November 2000. It does not take into account that the indigenous and ethnic population is a minority, nor that there would be municipalities in which there would be no support to present candidates, or there would be no interest to seek this support (para.223). According to the Court, the violations of the rights of the candidates proposed by Yatama are particularly serious because, there is a close relationship between the right to be elected and the right to vote to elect representatives. The exclusion of the candidates proposed by Yatama meant that they were not included among the options available to the voters, which represented a direct limitation to the exercise of the vote and affected negatively the broadest and freest expression of the will of the electorate, which implies grave consequences for democracy (para.226). ${ }^{75}$ Consequently, in Yatama the I-ACtHR establishes an inseparable link between the right to candidacy and the right to vote. ${ }^{76}$ In short, the rights to stand for election and to organize political opposition are essential elements of political participation. ${ }^{77}$

respect for the rights of the individual, the democratic representative form of government as well as the right of its peoples to development, self-determination, and the free disposal of their wealth and natural resources" (emphasis added). For the text see, Organization of American States, pp.65-75.

73 Davidson, The Inter-American Human Rights System, p.339; Davidson, "The Civil and Political Rights Protected in the IAHR System", p.281.

74 Joan Fitzpatrick, Human Rights in Crisis, Philadelphia, 1994, pp.63-66, 178-192; Joan Fitzpatrick, "States of Emergency in the Inter-American Human Rights System", in, The Inter-American System of Human Rights, David J. Harris and Stephen Livingstone (eds.), Oxford, 1998, pp.370-394, pp.375-376; Davidson, The Inter-American Human Rights System, p.339. Also see, Jaime Oraa, Human Rights in States of Emergency in International Law, Oxford, 1992, pp.14-16, 2227, 51-55, 81-83, 159-168, 197-200; Anna-Lena Svensson-McCarthy, The International Law of Human Rights and States of Exception, Leiden, 1998, pp.66-72, 115-120, 166-171, 242-284, 451-496; Gemalmaz, Ulusalüstü İnsan Hakları Hukukunun Genel Teorisi (General Theory of Supranational Human Rights Law), pp.355-356.

75 The IACtHR, Case of Yatama v. Nicaragua, Judgment of 23 June 2005, (Preliminary Objections, Merits, Reparations and Costs), Series C No.127 (emphasis added).

76 Johns, p.50.

77 Also see, Torres, p.598. 
The I-ACtHR gives particular importance to the independent candidates. In Castaneda Gutman v. Mexico, the Court held that "The systems that accept independent candidacies can be based on the need to expand and improve participation and representation in the management of public affairs and to enable a greater rapprochement between the citizens and the democratic institutions." 78

The Inter-American Court also recognizes positive obligations pertaining to electoral rights in Cepeda Vargas v. Colombia. According to the I-ACtHR, among other political rights, Article 23 of the Convention protects the right to be elected, which assumes that the beneficiary of these rights has a real opportunity to exercise them, which means that the effective measures must be adopted to guarantee the necessary conditions for their full exercise. ${ }^{79}$ The I-ACtHR here referred to Turkish political party cases brought before the European Court of Human Rights. ${ }^{80}$

In addition to I-ACtHR, the Inter-American Commission on Human Rights has firmly recognized the importance of democracy and associated political rights in protecting human rights. According to the Inter-American Commission, "... a democratic framework is an essential element for establishment of a political society where human values can be fully realized." ${ }^{81}$ The same is true, in view of the Inter-American Commission, with respect to Article 23 of the IACHR. Although Article 23, right to political participation leaves room for a wide variety of forms of government, this does not mean that State Parties are entirely immune from review by the Commission. States must show that the measures imposed on the exercise of such rights should be within the scope of permissible limitations. In any case the right to participate in government or any differential treatment imposed under this right should not lack any objective and reasonable justification. ${ }^{82}$

The Inter-American Commission is of the view that "if Article 23 of the IACHR is to be fully respected, elections should be authentic, universal, periodic, and by

I-ACtHR, Castaneda Gutman v. Mexico, Judgment of 6 August 2008, (Preliminary Objections, Merits, Reparations and Costs), Series C No.184, para.192.

79 I-ACtHR, Manuel Cepeda Vargas v. Colombia, Judgment of 26 May 2010, (Preliminary Objections, Merits, Reparations and Costs), Series C No.213, para. 172. Also see, I-ACtHR, Yatama v. Nicaragua, Judgment of 23 June 2005, (Preliminary Objections, Merits, Reparations and Costs), para.195; I-ACtHR, Castaneda Gutman v. Mexico, Judgment of 6 August 2008, (Preliminary Objections, Merits, Reparations and Costs), para.145. (“... It is essential that the State create optimum conditions and mechanisms to ensure that political rights can be exercised effectively, respecting the principle of equality and non-discrimination.")

80 ECtHR, Freedom and Democracy Party (OZDEP) v. Turkey, App. No.23885/94, Judgment of 8 December 1999, para.41; ECtHR, Socialist Party and Others v. Turkey, 20/1997/804/1007, Judgment of 25 May 1998, para.47.

81 IACHR, Doctrine of the Inter-American Commission on Human Rights (1971-1981), in, Ten Years of Activities 19711981, Washington, D.C., 1982, p.334; cited in, Francisco Forrest Martin/Stephen J. Schnably/Richard J. Wilson/ Jonathan S. Simon/Mark V. Tushnet, International Human Rights and Humanitarian Law: Treaties, Cases and Analysis, New York, 2006, pp.871-872.

82 Statehood Solidarity Committee v. United States, (Case 11.204, Report No. 98/03), Inter-Am. C.H.R., OEA/Ser./L/V/II.114 Doc. 5 rev. 1, 2003, paras.88, 89, 90. Also see, Alywin Azocar et al., v. Chile, (Merits), (Case 11.863, Report No. 137/99), Annual Report of the IACHR 1999, paras. 99, 101, 102. 
secret ballot or some other means that enabled voters to express their will freely." 83 In this decision the Inter-American Commission also draws a framework of the independence and impartiality of national election monitoring bodies. ${ }^{84}$

According to the Inter-American Commission, provisions that guarantee political rights, including Article XX of the American Declaration, must be interpreted and applied so as to give meaningful effect to exercise of representative democracy. ${ }^{85}$

The African system: The "African Charter on Human and Peoples' Rights" Banjul Charter) of 26 June 1981, Article 13/1 reads as follows: "Every citizen shall have the right to freely participate in the government of his country, either directly or through freely chosen representatives in accordance with the provisions of the law." ${ }^{87}$

Moreover, keeping in mind the specificity of its scope and context, a new instrument from the African region, namely "The African Charter for Popular Participation in Development and Transformation"88 (the Arusha Charter) of 16 February 1990 may also be noted. ${ }^{89}$

The African Commission on Human and Peoples' Rights has dealt with communications concerning the right to political participation. In Constitutional Rights Project v. Nigeria (Communication No.102/93), the African Commission has found the annulment of elections had violated Article 13/1 of the African Charter. ${ }^{90}$ One of the important aspects of the decision of the African Commission in Constitutional Rights Project v. Nigeria case is that it demonstrates the willingness of the Commission to adopt a wider protection of Article 13 of the African Charter on Human and Peoples' Rights. The Commission stated that: "The criteria what constitutes free and fair elections were internally agreed upon and it would be contrary to the logic or international law if a national government with a vested interest in the outcome of an election were the final arbiter of whether the election took place in accordance with international standards."

83 Luis Felipe Bravo Mena v. Mexico, (Case 10.956, Report No. 14/93), Inter-Am. C.H.R., OEA/Ser.L/V/II.85, rev., Doc 9, (7 October 1993). (At this point the Inter-American Commission also referred to its previous decision, see, (Report No. 01/90 on Cases 9768, 9780 and 9828 (Mexico), para.88).

${ }_{84}$ Bravo Mena v. Mexico, (Case 10.956, Report No. 14/93), Inter-Am. C.H.R., OEA/Ser.L/V/II.85, rev., Doc 9, (7 October 1993).

85 Statehood Solidarity Committee v. United States, (Case 11.204, Report No. 98/03), Inter-Am. C.H.R., OEA/Ser./L/V/II.114 Doc. 5 rev. 1, 2003, para.87.

86 The "African Charter on Human and Peoples' Rights" was adopted on 27 June 1981, and entered into force on 21 October 1981.

${ }_{87}$ Generally see, Christof Heyns, "Civil and Political Rights in the African Charter", in, The African Charter on Human and Peoples' Rights: The System in Practice, 1986-2000, Malcolm D. Evans and Rachel Murray (eds.), Cambridge, 2002, pp.137-177, pp.172-174.

88 "The African Charter for Popular Participation in Development and Transformation" was adopted at the International Conference on Popular Participation in the Recovery and Development Process in Africa, held in Arusha, 12-16 February 1990. Article 11 of the Arusha Charter defines "popular participation" as "The empowerment of ordinary people to effectively involve themselves in creating the structures and designing policies and programmes that serve the interests of all as well as to effectively contribute to the development process and share equally in its benefits."

89 Kofi Oteng Kufuor, "The African Charter for Popular Participation in Development and Transformation: A Critical Review", Netherlands Quarterly of Human Rights, Vol.18, No.1, March 2000, pp.7-22.

90 Constitutional Rights Project v. Nigeria (Communication No.102/93), Decision of 31 October 1998, Twelfth Activity Report of the African Commission on Human and Peoples' Rights: 1998-1999, Annex V. 
In its decision of 11 May 2000 in Sir Dawda K. Jawara v. the Gambia, the African Commission found that prohibition of political participation of former government members following a military coup d'etat was a violation of the Applicants' rights, and furthermore the coup d'etat itself a breach of people's right to freely choose their government. ${ }^{91}$

In Tanganyika Law Society and the Legal and Human Rights Centre v. The United Republic of Tanzania case, in which prohibition of independent candidacies were examined, The African Court on Human and Peoples' Rights concluded that the matter in question violated the right to directly participate in government. ${ }^{92}$ It is significant to note that, in addition to African Charter, the Applicants also relied on Article 21/1 of the UDHR and Articles 3 and 25 of the ICCPR. According to the African Court, the rights guaranteed in Article 13/1 of the African Charter "are not meant to be enjoyed only in association with some other individuals or group of individuals such as political parties". Thus, this provision not only protects collective aspects of political participation but also guaranteed a individual right. It follows that a legal requirement that a candidate must belong to a political party before she is enabled to participate in the governance of Tanzania "surely derogates the rights enshrined in Article 13/1 of the Charter". The African Court held that the Respondent failed "to show that the restrictions on the exercise of the right to participate freely in the government of the country by prohibiting independent candidates falls within the permissible restrictions set out in Article 27/2 of the Charter. In any event, the restriction on the exercise of the right through the prohibition on independent candidacy is not proportionate". ${ }^{93}$

\section{Democracy and The Right To Political Participation In The European Human Rights System}

The European Convention on Human Rights ${ }^{94}$ of 4 November 1950 (hereinafter referred to as ECHR or European Convention) is silent with regard to political participation rights. Nevertheless in so far as applicable in concrete cases, Article 9 on the right to freedom of thought, conscience and religion; Article 10 on the freedom of expression; Article 11 on the freedom of association and assembly, as well as

\footnotetext{
91 Sir Dawda K. Jawara v. the Gambia, (Communication Nos.147/95 and 1949/96), Decision of 11 May 2000, paras. 67, 73, Thirteenth Annual Activity Report of the African Commission on Human and Peoples' Rights: 1999-2000, Annex V, pp.96-108.

92 Johns, pp.50-51.

93 African Court on Human and Peoples' Rights, Tanganyika Law Society and the Legal and Human Rights Centre v. The United Republic of Tanzania and Reverend Christopher R. Mtikila v. The United Republic of Tanzania, App. Nos. 009/11 and 011/11, Ordinary Session of the ACtHPR, Judgment of 14 June 2013 (Merits), paras.91-107/2.

Apart from finding a violation of Article 13/1 of the African Charter (para.111), the Court also examines the issue in the light of Article 10/2 ("no one may be compelled to join an association"; Article 20 of the UDHR and Article 22 of the ICCPR) of the Charter. The African court is of the view that freedom of association is negated if an individual is forced to associate with others, and this freedom is also negated if other people are forced to join up with the individual, (para.113). Consequently, the Court finds that by requiring individuals to belong to and to be sponsored by a political party in seeking election for the elective posts, the Respondent has also violated the right to freedom of association, (para.114).

94 The "Convention for the Protection of Human Rights and Fundamental Freedoms" ("European Convention on Human Rights") was adopted on 4 November 1950, and entered into force on 3 September 1953.
} 
Article 14 on the prohibition of discrimination are relevant provisions of the ECHR in relation to political rights.

The normative gap of right to political participation in the European Convention was partially filled by the adoption of the Protocol No.1 of the Convention on 20 March $1952 .{ }^{95}$ So one may safely conclude that at the regional level human rights instruments of the post Second World War era, right to political participation was first recognized by the Council of Europe which incorporated the right into the European Convention system in early 1950's.

Article 3 of Protocol No. ${ }^{96}$ (hereinafter referred to as P1-3) to the European Convention reads as follows:

"Article 3 - The High Contracting Parties undertake to hold free elections at reasonable intervals by secret ballot, under conditions which will ensure the free expression of the opinion of the people in the choice of the legislature."

In comparison with the relevant provisions of other human rights instruments indicated above (eg., Article 25 of the ICCPR), the narrower scope of the P1-3 to the European Convention is evident. Indeed, the wording of the P1-3 does not provide universal suffrage and/or genuine elections, does not include prohibition of discrimination, and does not indicate political participation as an individual right or a clear recognition standing to individuals. ${ }^{97}$

These normative shortcomings, however, might be less serious as it appears at first sight. (i) Apart from assessment indicated below, it is fair to admit that the European

95 The "Protocol No. 1 to the Convention for the Protection of Human Rights and Fundamental Freedoms, securing certain rights and freedoms other than those already included in the Convention" was opened for signature on 20 March 1952, and entered into force on 18 May 1954.

96 Literature: Jan de Meyer, "Electoral Rights", in, The European System for the Protection of Human Rights, Macdonald et al. (eds.), Leiden, 1993, pp.553-569; J. G. Merrills, The Development of International Law by the ECHR, Manchester, 1993 ( $2^{\text {nd }}$ ed.), pp.125-128; K. Herndl, "The Case-law of the Commission as regards the Right to Free Elections (Article 3 of Protocol 1)", in, The Birth of European Human Rights Law (Liber Amicorum Carl Aage Norgaard), Michele de Salvia - Mark E. Villiger (eds.), Baden-Baden, Germany, 1998, pp.91-99; Clare Ovey/Roben C. A. White, Jacobs \&. White, The European Convention on Human Rights, Oxford - New York, 2002, pp.331-338; Burchill, pp.145-150; Karen Reid, A Practitioner's Guide to the European Convention on Human Rights, , England, 2004 ( $2^{\text {nd }}$ ed.), pp.275-283; Jeroen Schokkenbroek, "Free Elections by Secret Ballot (Article 3 of Protocol No.1)", in, Theory and Practice of the ECHR, van Dijk, et al., (eds.), 2006 (4 ed.), pp.911-935; Davis J. Harris/Michael O'Boyle/Colin Warbrick, Law of the European Convention on Human Rights, Oxford - New York, 2009 ( $2^{\text {nd }}$ ed.), pp.711-733; Achilles C. Emilianides, "Do Minimum Age Requirements Violate the Right to Stand for Election under the European Convention on Human Rights?", European Human Rights Law Review, No.5, 2009, pp.670-683; Sergey Golubok, "Right to Free Elections: Emerging Guarantees or Two Layers of Protection?", Netherlands Quarterly of Human Rights, Vol.27, No.3, September 2009, pp.361-390; Michael O'Boyle, "Electoral Disputes and the ECHR: An Overview", Human Rights Law Journal, Vol.30, No.1-12, 2009-2010, pp.1-12; Binder, pp.443-445; Elizabeth Raulston, "(Un)Justifiable?: A Comparison of Electoral Discrimination Jurisprudence at the European Court of Human Rights and the Constitutional Court of Bosnia and Herzegovina", American University International Law Review, Vol.28, No.2, 2013, pp.669-706; Alastair Mowbray, "Contemporary Aspects of the Promotion of Democracy by the European Court of Human Rights”, European Public Law, Vol.20, No.3, 2014, pp.469-498, pp.488-497; William Schabas, The European Convention on Human Rights: A Commentary, Oxford, 2015, pp.1011-1032; Cristina Fasone/Giovanni Piccirilli, "Towards a Ius Commune on Elections in Europe? The Role of the Code of Good Practice in Electoral Matters in 'Harmonizing' Electoral Rights", Election Law Journal, Vol. 16, No.2, 2017, pp.247-254; Gemalmaz, Ulusalüstü İnsan Hakları Hukukunun Genel Teorisi (General Theory of Supranational Human Rights Law), pp.102-105.

${ }_{97}$ Fox, "The Right to Political Participation in International Law", p.560; Schabas, 2015, pp.118-119. 
Court of Human Rights (hereinafter referred to as ECtHR or Court or European Court) interpreted the P1-3 going beyond this literal narrow scope.

(ii) Inclusion of the prohibition of discrimination clause into the P1-3 might result in an unnecessary duplication, since such prohibition clause has already been provided in (Article 14) of the European Convention and under the Convention system there is no barrier for potential applicants to submit alleged violations of either P1-3 alone or in conjunction with Article 14 of the Convention. In fact, in the judgments and decisions which are examined below, the applicants also submitted allegations concerning violations falling the scope of the second category. Moreover, Protocol No. 12 enshrines self-standing discrimination clause which is also applicable in electoral matters. The limited number of prohibition of discrimination grounds ${ }^{98}$ indicated in Article 14 of the Convention has already been enlarged by the jurisprudence of the European Court, which is in line with the jurisprudence of other human rights bodies. ${ }^{99}$

(iii) Although it is not formulated as a right or freedom in text of P1-3, the European Court has consistently stated that this provision also implies individual rights, including the right to vote (active aspect) and the right to stand for election (passive aspect). ${ }^{100}$

If one takes into account of the Preamble ${ }^{101}$ to the ECHR ${ }^{102}$ and preparatory works in respect of $\mathrm{P} 1-3^{103}$, it is natural to link democracy and human rights as inseparable features of European public order. ${ }^{104}$ In that regard, one should be reminded that the ECHR was

98 Gemalmaz, Ulusalüstü İnsan Hakları Hukukunun Genel Teorisi (General Theory of Supranational Human Rights Law), pp.102-105. (The grounds of prohibition of discrimination in international human rights instruments, $i d$. ., pp.102-103, and regional instruments, id., pp.104-105.)

99 Mehmet Semih Gemalmaz, "Ulusalüstü İnsan Hakları Hukukunda Ayrımcıllk Yasağı ve Eșitlik İlkesi” (Prohibition of Discrimination and Equality Principle in Supranational Human Rights Law), Prof. Dr. Tunçer Karamustafaoğlu'na Armağan, 2010, pp.248-250; Gemalmaz, Ulusalüstü İnsan Hakları Hukukunun Genel Teorisi (General Theory of Supranational Human Rights Law), pp.689-690.

100 Mathieu-Mohin and Clerfayt v. Belgium, App. No.9267/81, Judgment of 02 March 1987, Series A, No. 113, paras.46-51. Also see, Zdanoka v. Latvia, App. No. 58278/00, Grand Chamber Judgment of 16 March 2006, para.102; Campagnano v. Italy, App.77955/01, Judgment of 23 March 2006, para.44; Lykourezos v. Greece, App. No.33554/03, Judgment of 15 June 2006, para. 50. Also see, O’Boyle, "Electoral Disputes and the ECHR", pp.3-9.

101 The ECtHR has recognized the Preamble to the ECHR as part of the context of the substantive text and indicative of its object and purpose. See Golder v. United Kingdom, App. No.4451/70, Judgment of 21 February 1975, para.34 (The ECtHR here referred to Article 31 para. 2 of the Vienna Convention of 23 May 1969 on the Law of Treaties). Also see, Steven Greer, The European Convention on Human Rights: Achievements, Problems and Prospects, Cambridge, 2006, p.196.

102 Relevant parts of the Preamble to the European Convention on Human Rights reads as follows: “...(R)eaffirming their profound belief in those fundamental freedoms which are the foundation of justice and peace in the world and are best maintained on the one hand by an effective political democracy and on the other by a common understanding and observance of the human rights upon which they depend." (emphasis added).

103 For detailed analyses of preparatory works in respect of P1-3, see, Schabas, pp.1012-1018; Francesca Viviani, Right to Free Elections in the Case-Law of the European Court of Human Rights, Bachelor's Degree Thesis, Luiss Guido Carli, 2012/2013, pp.6-21, in particular pp.12-15; Harris/O'Boyle/Warbrick, pp,711-712; Susan Marks, “The European Convention on Human Rights and its 'Democratic Society"', British Yearbook of International Law, Vol.66, No.1, January 1996, pp.209-238, pp.220-221; Burchill, p.147; Golubok, pp.364-367. O'Boyle, "Electoral Disputes and the ECHR”, p.1; Binder, p.443; Fox, "The Right to Political Participation in International Law", pp.561-562.

104 Zdanoka v. Latvia, App. No. 58278/00, Grand Chamber Judgment of 16 March 2006, para. 98. Also see, Council of Europe, Guide on Article 3 of Protocol No. 1 to the European Convention on Human Rights - Right to Free Elections, Updated on 31 August 2017, Council of Europe, 2017, p.6. 
designed to promote and maintain the ideals and values of a democratic society. ${ }^{105}$ The ECtHR, as argued at the end of the last century, "has generally developed and applied its concept of democracy in a progressive manner which has sought to enhance and safeguard the vitality of the political process operating in Member States." ${ }^{\text {106 }}$

P1-3 lies at the core of democratic government based on the consent of the people and in conformity with the principles of the Convention. The Court has several times emphasized that the rights guaranteed by P1-3 are crucial in establishing and maintaining the foundations of a meaningful democracy governed by the rule of law. ${ }^{107}$ The Court firmly indicates that "democracy constitutes a fundamental feature of the "European public order" and that it "is the only political model contemplated by the Convention and, accordingly, the only one compatible with it." 108

The European Court described the State as the ultimate guarantor of the principle of pluralism. In the political sphere that responsibility means that the State is under the obligation, among others, to hold, in accordance with P1-3, free elections at reasonable intervals by secret ballot under conditions which will ensure the free expression of the opinion of the people in the choice of the legislature. ${ }^{109}$

In accordance to the wording of the P1-3, the primary duty of the Governments is to undertake and to organize democratic elections under conditions which will ensure the free expression of the people. ${ }^{110}$ This obligation is obviously and explicitly a positive one. ${ }^{111}$

Since there could be no democracy without pluralism, and plurality of political parties is a prerequirement in providing such pluralism $^{112}$, a one-party political system

${ }_{105}$ Marks, "The European Convention on Human Rights and its 'Democratic Society", pp.209-238; Alastair Mowbray, "The Role of the European Court of Human Rights in the Promotion of Democracy", Public Law, 1999, pp.703-725; Conor Gearty, "Democracy and Human Rights in the European Court of Human Rights: A Critical Appraisal", Northern Ireland Legal Quarterly, Vol.51, 2000, pp.381-396; Greer, The ECHR: Achievements, Problems and Prospects, pp.199200; Mowbray, "Promotion of Democracy by the ECtHR", pp.469-498. In the context of Article 10 and Article 11 of the Convention see, Christian Democratic People's Party v. Moldova, App. No.28793/02, Judgment of 14 February 2006, para. 63.

106 Mowbray, "The Role of the ECtHR in the Promotion of Democracy", p.725.

107 Zdanoka v. Latvia, App. No. 58278/00, Grand Chamber Judgment of 16 March 2006, para. 103; Yumak and Sadak v. Turkey, App. No.10226/03, Grand Chamber Judgment of 16 March 2008, para. 105.

108 Zdanoka v. Latvia, App. No. 58278/00, Grand Chamber Judgment of 16 March 2006, para. 98; United Communist Party of Turkey and Others v. Turkey, App. No.19392/92, Judgment of 30 January 1998, para. 45. Also see, Greer, The ECHR: Achievements, Problems and Prospects, p.199.

109 Christian Democratic People's Party v. Moldova, App. No.28793/02, Judgment of 14 February 2006, para.66.

110 Yumak and Sadak v. Turkey, App. No.10226/03, Grand Chamber Judgment of 16 March 2008, para. 106.

111 In fact, the Court interprets inter-state wording of P1-3 as the desire to give greater solemnity to the commitment undertaken by the Contracting States and emphasize that this is a sphere in which they are under an obligation to take positive measures and not just refrain from interference (See, Mathieu-Mohin and Clerfayt v. Belgium, Judgment of 02 March 1987, para 50; United Communist Party of Turkey and Others v. Turkey, App. No.19392/92, Judgment of 30 January 1998, para. 33). For "positive obligations" specifically see, Alastair Mowbray, The Development of Positive Obligations under the European Convention on Human Rights by the European Court of Human Rights, Oxford - Portland Oregon, 2004 (This study does not include P13, only focuses on the Convention rights); Harris/O'Boyle/Warbrick, p.18-20, 342-343, 446-447; Schokkenbroek, "Free Elections by Secret Ballot (Article 3 of Protocol No.1)", pp.912-916; Golubok, pp.378-379; Johns, pp.31, 33.

112 United Communist Party of Turkey and Others v. Turkey, App. No.19392/92, Judgment of 30 January 1998, paras.43, 44. 
cannot be compatible with P1-3. ${ }^{113}$ The Court also underlines that it is of the essence of democracy to allow diverse political programmes to be proposed and debated, even those that call into question the way a State is currently organized, provided that they do not harm democracy itself. ${ }^{114}$

States have a limited margin of appreciation ${ }^{115}$ to justify dissolving political parties since they assume crucial role for the proper functioning of a democratic regime. ${ }^{116}$ The same standard is also applicable with respect to the right to form an association, which is inherently part of the right set forth in Article 11 of the Convention. ${ }^{117}$

As the "implied limitations" concept has been applied to P1-311, the Court does not apply the "necessity" or "pressing social need" criteria which are used with regard to Articles 8-11 of the ECHR. ${ }^{119}$ However it should be noted that the jurisprudence of the ECtHR on the "necessary in a democratic society" phrase as provided in (Articles 8-11) of the European Convention, implies that a democratic regime requires the compliance of human rights and imposes an obligation to maintain a democratic regime ${ }^{120}$ in which individual human rights are not only recognized, but also effectively respected and protected. ${ }^{121}$

P1-3 presupposes the existence of a representative legislature, elected at reasonable intervals. ${ }^{122}$ With respect to the right to free elections the European Court has already examined some cases. For example, the ECtHR dealt with the dissolution of political parties and the termination of parliamentary mandates of members of opposition parties and their subsequent imprisonment for alleged separatist activities. The Court held that "the measure was incompatible with the very essence of the right to stand for election and to hold Parliamentary office and that it had infringed the unfettered discretion of the electorate which had elected the applicants." ${ }^{123}$

\footnotetext{
113 Schokkenbroek, "Free Elections by Secret Ballot (Article 3 of Protocol No.1)", p.913.

114 Socialist Party and Others v. Turkey, 20/1997/804/1007, Judgment of 25 May 1998, para. 47.

115 Soren C. Prebensen, "The Margin of Appreciation and Articles 9, 10 and 11 of the Convention”, Human Rights Law Journal, Vol.19, No.1, April 1998, pp.13-17, p.16.

116 United Communist Party of Turkey and Others v. Turkey, App. No.19392/92, Judgment of 30 January 1998, para. 46. For the reaffirmation of the same standard also see, Socialist Party and Others v. Turkey, 20/1997/804/1007, Judgment of 25 May 1998, para.50.

117 Sidiropoulos and Others v. Greece, 57/1997/841/1047, Judgment of 10 July 1998, para. 40; Tebieti Muhafize Cemiyyeti and Israfilov v. Azerbaijan, App. No.37083/03, Judgment of 8 October 2009, para.67.

118 Mathieu-Mohin and Clerfayt v. Belgium, App. No.9267/81, Judgment of 02 March 1987, para. 52.

119 Reid, p.275; Harris/O'Boyle/Warbrick, pp.713-714; Golubok, pp.371-376; Schabas, p. 1024

120 In general see, D'Aspremont, p.896; Mowbray, “The Role of the ECtHR in the Promotion of Democracy”, pp.703-704; Gearty, pp.381-382.

121 Yutaka Arai-Takahashi, The Margin of Appreciation Doctrine and The Principle of Proportionality in the Jurisprudence of the ECHR, Antwerp, 2002, pp.125-128; Greer, The ECHR: Achievements, Problems and Prospects, pp.199-200.

122 The Greek Case, Yearbook ECHR, Vol.12, 1969, p.179. Also see, Schokkenbroek, "Free Elections by Secret Ballot (Article 3 of Protocol No.1)", p.912; Reid, p.281; Merrills, p.126

123 Sadak and Others v. Turkey (No.2), App. Nos.25144/94, 26149/95 to 26154/95, 27100/95 and 27101/95, Judgment of 11 June 2002.
} 
The ECtHR has also found a violation which includes the prerequisite that candidates for parliamentary elections have adequate command of the official language ${ }^{124}$ and the continued suspension of the right to vote of a suspected criminal after he was acquitted. ${ }^{125}$ Furthermore, the Court has also found violations in a case of the disenfranchisement of convicted prisoners ${ }^{126}$ and refusal to register the applicant on the electoral roll because he was a member of the Turkish-Cypriot community. ${ }^{127}$ With respect to disenfranchisement in recent Turkish cases, the Court found that such a measure shall be indiscriminative when it fails to take into account the nature or gravity of the offence, the length of the sentence, and the individual circumstances of the convicted person. ${ }^{128}$ In Melnychenko v. Ukraine the Court found that the right which is guaranteed by P1-3 "would be illusory if one could be arbitrarily deprived of it at any moment... The principle that rights must be effective requires that the eligibility procedure contain sufficient safeguards to prevent arbitrary decisions." 129

On the other hand, in the opinion of the Court restrictions on the right to stand for elections should be compatible with the proportionality test, i.e. it must pursue a legitimate aim and the methods of achieving the aim pursued must not be disproportionate. ${ }^{130}$ For example, in a case concerning restriction on the right to stand for elections following a bankruptcy order, the Court concluded that the measure in question did not pursue a legitimate aim. The Court also stressed that "voting is not a privilege but a right guaranteed by the Convention."131

Nonetheless there are numerous cases in which the Court granted a "wide margin of appreciation" with respect to (Articles 8-15) of the Convention in general ${ }^{132}$, and

124 Podkolzina v. Latvia, App. No.46726/99, Judgment of 9 April 2002.

${ }^{125}$ Labita v. Italy, App. No.26772/95, Grand Chamber Judgment of 6 April 2000.

126 Hirst v. the United Kingdom (No.2)", App. No.74025/01, Grand Chamber Judgment of 06 October 2005; Greens and M.T. v. the United Kingdom, Judgment of 23 November 2010, para.77. Also see, Harris/O'Boyle/Warbrick, pp.717-719; O'Boyle, "Electoral Disputes and the ECHR", pp.5-6; Reid, pp.276-277; Binder, p.444.

127 Aziz v. Cyprus, App. No.69949/01, Judgment of 22 June 2004, para.28. The Court concluded that there was a violation of P1-3; the States must not "exclude some persons or group of persons from participating in the political life of the country."

128 Söyler v. Turkey, App. No.29411/07, Judgment of 17 September 2013, paras.36-47; Murat Vural v. Turkey, App. No.9540/07, Judgment of 21 October 2014, paras.77-80.

129 Melnychenko v. Ukraine, App. No.17707/02, Judgment of 19 October 2004, para.59.

130 Campagnano v. Italy, App.77955/01, Judgment of 23 March 2006. Also see, See, Gitonas and Others v. Greece, Judgment of 01 July 1997, para.39.

131 Campagnano v. Italy, App.77955/01, Judgment of 23 March 2006, para.49.

132 Clovis Morrison Jr., "Margin of Appreciation in European Human Rights Law", Human Rights Journal/Revue des Droits de l'Homme, Vol.6, 1973, pp.263-286; Thomas O'Donnell, “The Margin of Appreciation Doctrine: Standards in the Jurisprudence of the European Court of Human Rights", Human Rights Quarterly, Vol.4, 1982, pp.474-496; Paul Mahoney, "Judicial Activism and Judicial Self-restraint in the European Court of Human Rights: Two Sides of the Same Coin", Human Rights Law Journal, Vol.11, Parts 1-2, 1990, pp.57-88, pp.78-85; Laurence R. Helfer, "Consensus, Coherence and the European Convention on Human Rights", Cornell International Law Journal, Vol.26, 1993, pp.133-165, pp.136-138; Merrills, pp.151-176. Howard Charles Yourow, The Margin of Appreciation Doctrine in the Dynamics of European Human Rights Jurisprudence, The Hague-Boston-London, 1996; Nicholas Lavender, "The Problem of the Margin of Appreciation", European Human Rights Law Review, No.4, 1997, pp.380-390; Juliane Kokott, The Burden of Proof in Comparative and International Human Rights Law, The Hague - London - Boston, 1998, pp.218-233; Eyal Benvenisti, "Margin of Appreciation, Consensus, and Universal Standards", New York University Journal of International Law and Politics, Vol.31, 1999, pp.843-854; Michael R. Hutchinson, "The Margin of Appreciation Doctrine in the European Court 
P1-3 in particular. ${ }^{133}$ The ECtHR repeatedly underlines that the rights provided by the P1-3 are not absolute ${ }^{134}$, and indicates that "there are numerous ways of organizing and running electoral systems and a wealth of differences... in historical development, cultural diversity and political thought within Europe". Consequently, "it is for (each) country... to mould into their own democratic vision." 135 For example, with regard to the conditions on the rights to vote and stand for elections, including standards for disqualification ${ }^{136}$, the choice of voting system or voter registration system ${ }^{137}$, States have wide margin of appreciation. In view of the Court, the restrictions on the right set forth in P1-3 may be justified on the "ground of pressing significance to the democratic order."138

However, neither putting restrictions on voting rights (including disenfranchising), nor not allowing individuals to vote for any of candidates (including independent candidates) running for election permit unreasonable and excessive limitations. ${ }^{139}$ In other words, possibility of imposing restrictions on the right to vote does not mean that any or all types of restrictions are allowed. Only restrictions compatible with the proportionality principle are permitted. It follows that possible restrictions on the right of political participation may only be justified if they do not "harmful to democracy itself'. ${ }^{140}$

Despite its importance, the jurisprudence concerning P1-3 still has many flaws and inconsistencies with regard to both general principles surrounding right to vote and the right to stand for election and their application to specific cases.

of Human Rights", International and Comparative Law Quarterly, Vol.48, No.3, July 1999, pp.638-650; Paul Mahoney, "Marvellous Richness of Diversity or Invidious Cultural Relativism?", Human Rights Law Journal, Vol.19, No.1, April 1998, pp.1-6; Prebensen, pp.13-17; Jeroen Schokkenbroek, "The Prohibition of Discrimination in Article 14 of the Convention and the Margin of Appreciation", HRLJ, Vol.19, No.1, 1998, pp.20-23; Michael O'Boyle, "The Margin of Appreciation and Derogation under Article 15", HRLJ, Vol.19, No.1, 1998, pp.23-29; Oren Gross/Fionnuala Ni Aolain, "From Discretion to Scrutiny: Revisiting the Application of Margin of Appreciation Doctrine", Human Rights Quarterly, Vol.23, No.3, 2001, pp.625-649; Eva Brems, "The Margin of Appreciation Doctrine of the European Court of Human Rights: Accommodating Diversity Within Europe", in, Human Rights and Diversity: Area Studies Revisited, (edited by David P. Forsythe and Patrice C. McMahon), Lincoln and London, 2003, pp.81-110; Jeffrey A. Brauch, "The Margin of Appreciation and the Jurisprudence of the European Court of Human Rights: Threat to the Rule of Law", Columbia Journal of European Law, Vol.11, 2005, pp.113-150; Steven Greer, "The Interpretation of the European Convention on Human Rights: Universal Principle or Margin of Appreciation?”, UCL Human Rights Law Review, Vol.3, 2010, pp.1-14.

133 Detailed analyses of margin of appreciation in the context of P1-3 see, Viviani, Right to Free Elections in the Case-Law of the European Court of Human Rights, Bachelor's Degree Thesis, Luiss Guido Carli, 2012/2013, pp.43-51; Golubok, pp.375-376.

134 Merrills, pp.126-127; Reid, p.275; Schokkenbroek, "Free Elections by Secret Ballot (Article 3 of Protocol No.1)", pp.917-918; Golubok, p.376; Schabas, pp.1023, 1024.

135 See, Hirst v. the United Kingdom (No.2)", App. No.74025/01, Grand Chamber Judgment of 06 October 2005, para.61.

136 Gitonas and Others v. Greece, Judgment of 01 July 1997; Vito Sante Santoro v. Italy, App. No.36681/97, Judgment of 01 July 2004

137 Mathieu-Mohin and Clerfayt v. Belgium, App. No.9267/81, Judgment of 02 March 1987, para.52; Vito Sante Santoro v. Italy, App. No.36681/97, Judgment of 01 July 2004, para.54; Georgian Labor Party v. Georgia, App. No.9103/04, Judgment of 8 July 2008, para. 90. Also see, Golubok, pp.375-376; Mowbray, "Promotion of Democracy by the ECtHR", pp.489-490.

138 Lykourezos v. Greece, App. No.33554/03, Judgment of 15 June 2006, para.57. In this case the Court also found that a limitation could be considered arbitrary if the new laws are applied retroactively to the detriment of already elected parliamentarians.

$139 C f$., Golubok, p.373.

140 Wheatley, p.225. 


\title{
IV) Critical Remarks On The Jurisprudence Of The European Court Of Human Rights Concerning Independent Candidates
}

\section{A. Preliminary Remarks on the ECtHR's Use of Margin of Appreciation Doctrine in Electoral Cases}

As mentioned earlier above, the ECtHR gives almost unlimited discretion to States in limiting electoral rights under P1-3. In fact, the margin of appreciation doctrine always the main reason for the ECtHR to reach non-violation conclusions in electoral cases. Accordingly, in order to understand the rationale behind specific judgments and decisions concerning P1-3, one first should consider the use and abuse of margin of appreciation doctrine by the ECtHR.

It seems that unlimited margin of appreciation for States in electoral matters was based on the traditional international law of non-intervention in the internal affairs of states. This nonintervention in domestic electoral matters is reflected in the judgment of the International Court of Justice (ICJ) in Nicaragua v. United States of America. ${ }^{141}$ The ICJ stated that

\begin{abstract}
"State's domestic policy falls within its exclusive jurisdiction, provided of course that it does not violate any obligation of international law. Every State possesses a fundamental right to choose and implement its own political, economic and social systems. Consequently, there would normally be no need to make any enquiries, in a matter outside the Court's jurisdiction, to ascertain in what sense and along what lines Nicaragua has actually exercised its right."142
\end{abstract}

The ICJ also stated that "... The Court cannot find an instrument with legal force, whether unilateral or synallagmatic, whereby Nicaragua has committed itself in respect of the principle or methods of holding elections." ${ }^{\text {43 }}$

Although the ECtHR never mentioned the ICJ's holding or any international law materials concerning non-intervention or national discretion to adopt any electoral policy, its reasoning no doubt affected by the reasoning of ICJ while granting states almost unlimited margin of appreciation under P1-3 regardless of electoral issue before it.

Admittedly, the margin of appreciation doctrine serves to reconcile two competing interests under P1-3. As Judge Letvis clearly put in his dissenting opinion in Zdanoka v. Latvia case: ${ }^{144}$

"When examining applications under Article 3 of Protocol No. 1, the Court always faces a certain dilemma: on the one hand, of course, it is the Court's task to protect the electoral

\footnotetext{
${ }^{141}$ Crawford, p.121. Also see, Christian Pippan, "International Law, Domestic Political Orders and the 'Democratic Imperative': Has Democracy Finally Emerged as a Global Legal Entitlement?”, Jean Monnet Working Paper No 2/10, New York, 2010, p.23; Binder, pp.439-440.

142 "Military and paramilitary activities in and against Nicaragua (Nicaragua v. United States of America)", Judgment of 27 June 1986 (Merits), ICJ Reports 1986, pp.14-150, especially pp.130-131, para.258.

143 Id., pp.131-132, paras.259, 261.

144 Zdanoka v. Latvia, App. No. 58278/00, First Chamber Judgment of 17 June 2004, Dissenting Opinion of Judge Levits, paras.17-18.
} 
rights of individuals; but, on the other hand, it should not overstep the limits of its explicit and implicit legitimacy and try to rule instead of the people on the constitutional order which this people creates for itself.

This dilemma is unique problem within the Convention system, because only the rights in Article 3 of Protocol No. 1 have this double legal character as human rights and an important element of national constitutional order.

The appropriate way out of this dilemma is to use the instrument of margin of appreciation..." (emphasis original).

Some authors argue, however, that granting States a wide margin of appreciation by the European Court constitutes a threat to the rule of law ${ }^{145}$ :

"There is little doubt that the Court is well intentioned. It wants to appropriately balance individual rights with significant government interests. And it has created a doctrine to help it achieve that balance. Unfortunately, the Court has used this judicially created tool to the exclusion of the text, of legal analysis, and indeed of the rule of law. It has taken on the role of a supranational legislature making policy judgments for the nations of Europe, judgments that lack basic rule of law requirements of clarity, predictability, equality, and non-arbitrariness. The Court must return to the text. It must abandon the margin of appreciation."146

Morever, one must take into account of the new developments in the field of traditional international law of non-intervention in the internal affairs of states. It may fairly be argued that these concerns and justifications lost their meaning in the world of the 21 th century. ICJ's justifications based on traditional non-intervention doctrine mostly lost their validity after the end of the Cold War. After the collapse of Berlin Wall, the lack of international concern for domestic electoral processes significantly changed as demonstrated above in detail, at least in theory. Since the fall of the Cold War era, it has been argued that the legitimacy of governments should no further be assessed only through national criteria, but also through the universal criterion of democracy. ${ }^{147}$ Therefore, the need to grant states wide margin of appreciation in electoral matters has been eliminated.

The present author is of the opinion that it is going too far to suggest the total abandonment of the margin of appreciation. There are reasonable grounds for the justification of the doctrine. ${ }^{148}$ Although classical non-intervention doctrine lost its weight after Cold War especially in international human rights law, States are still primarily actors to organize electoral systems on the basis of their needs, historical

\footnotetext{
45 Brauch, pp.113-150. Also see, Jan Kratochvil, "The Inflation of the Margin of Appreciation by the European Court of Human Rights”, Netherlands Quarterly of Human Rights, Vol. 29/3, 2011, pp. 324-325 and fn. 1-2.

146 Brauch, p.150.

147 Franck, "The Emerging Right to Democratic Governance”, pp.46-91; D’Aspremont, p.889; Besson, pp.50-51.

148 Mahoney, "Judicial Activism and Judicial Self-restraint in the ECtHR", pp.78-80, 83-85; Helfer, pp.137-138. Yourow, p.197; Mahoney, "Marvellous Richness of Diversity or Invidious Cultural Relativism?", pp.2-4, 6; Benvenisti, pp.845846; Burchill, p.148; Brems, pp.82-94.
} 
development, cultural diversity and political thought. Even international human rights law is bound by the principle of subsidiarity.

However, the problem with margin of appreciation doctrine mainly emanates from its excessive and inconsistent use. ${ }^{149}$ This doctrine cannot be called for when political rights of members of minority groups are prevented through, such as, restrictions on speech or on association. ${ }^{150}$

In fact, an unlimited margin of appreciation in electoral matters prevents the ECtHR to make clear and concrete assessments about the real situations before it. Such an excessive margin of appreciation is not compatible with the principle of effectiveness and living instrument doctrine. The principle of effectiveness and living instrument doctrine have become interpretive means in order to provide the compliance with the object and purpose of the Convention.

To put curb on the ECtHR's excessive use of margin of appreciation doctrine, one should take consensus approach/doctrine ${ }^{151}$ into account. ${ }^{152}$ The basic method of consensus approach is to make reference back to national legal systems of the State Parties, which indicates whether or not an emerging trend between member States of the Council of Europe exists on the subject matter before the Court. The method, which is also known as "comparative method"153, is very useful in order to describe the present-day conditions with regard to complicated human rights

\footnotetext{
49 Mahoney, "Judicial Activism and Judicial Self-restraint in the ECtHR", pp.80-83; Yourow, pp.197-198; Mahoney, "Marvellous Richness of Diversity or Invidious Cultural Relativism?", pp.4-5; Kokott, p.221 ("Recognition of a national margin of appreciation is indispensable under international human rights law. Extensive recourse to the national margin, however, risks rendering the international protection of human rights ineffective, because the margin of appreciation imposes burden of proof upon individual. Therefore, the correct balance must be struck... International supervision can only be effective, predictable, and acceptable to states if alternative standards of scrutiny are applied consistently."); Benvenisti, p.847 ("While resort to the margins doctrine may be justified in certain matters that affect the general population in a given society, the doctrine is inappropriate when conflicts between majorities and minorities are examined."); Brems, p.105 (“... the lack of explanation given by the Court itself continues to give an impression of arbitrariness. When the European Court uses margin of appreciation analysis, it should explain its reasons, the criteria widening or restricting the margin, and the weight of the margin of appreciation in the outcome of the case."); Burchill, pp.147-148; ("The court's use and development of the margin of appreciation has been inconsistent and vague, leading to question over its proper place within the ECHR framework."); Greer, "The Interpretation of the ECHR: Universal Principle or Margin of Appreciation?", p.14; ("The margin of appreciation doctrine is integral and essential to the Convention's system of constitutionalinterpretive principles... The best that can be hoped for is that the margin of appreciation is confined within acceptable limits, mainly by appreciating its subordination to the Convention's primary constitutional principles and also its relationship with other secondary principles, particularly proportionality."). Also see, Yuval Shany, "Toward a General Margin of Appreciation Doctrine in International Law?", European Journal of International Law, Vol.16, No.5, 2005, pp.907-940, pp.912-914; Jan Kratochvil, "The Inflation of the Margin of Appreciation by the European Court of Human Rights", Netherlands Quarterly of Human Rights, Vol. 29/3, 2011, pp. 324-357.

150 Benvenisti, p.847.

151 For the consensus approach see H. Burak Gemalmaz, "Transformative Interpretation in International Human Rights Law: Elements of an Obligatory Judicial Dialogue Between International Judicial and Quasi-Judicial Organs", 9th World Congress of Constitutional Law, 2014, Oslo University Faculty of Law, 16-20 June 2014, Norway (http://www.jus.uio.no/ english/research/news-and-events/events/conferences/2014/wccl-cmdc/wccl/papers/ws5/w5-gemalmaz.pdf); Mahoney, "Judicial Activism and Judicial Self-restraint in the ECtHR", pp.62-88; Helfer, pp.138-165; Yourow, pp.193-196; Benvenisti, pp.850-853; Arai-Takahashi, pp.215-216; Brems, p.106.

152 Shai Dothan, "Judicial Deference Allows European Consensus to Emerge”, iCourts Working Paper Series, No. 22, 2015, p.7-8.

153 Cf. Paolo G. Carozza, "Uses and Misuses of Comparative Law in International Human Rights: Some Reflections on the Jurisprudence of the European Court of Human Rights", Notre Dame Law Review, 1998, Vol. 73, at 1219 and fn. 8 (He has not considered this activity of the Court as "method" or "analysis" since he argued that "there appears to be little analysis and even less method involved").
} 
issues and hard cases. ${ }^{154}$ Moreover, the consensus approach is also compatible with the very existential principles of the ECHR since the reference to national legal or societal order of member States of Council of Europe in interpreting and applying the Convention has its source in the principle of subsidiarity. ${ }^{155}$ A State Party that breaches the consensus may be found in violation of the Convention. If no consensus exists, the margin of appreciation is relatively wide and therefore the possibility of the compliance with the Convention is wider. ${ }^{156}$

However, despite frequently used by the Court, it has been criticized as being superficial. In this regard, the lack of certain criteria for the selection of States for comparison, lack of the collection of empirical data and proper analyses of it and lack of the quantitative element which indicates whether a consensus exists would undermine the credibility of the comparative activity. ${ }^{157}$ Furthermore, some argue that consensus approach is not compatible with universality and autonomy of human rights. ${ }^{158}$ Morevover, the Court sometimes uses the consensus approach/doctrine while determining the width of the margin of appreciation inappropriate manner. For example, in Yumak and Sadak ruling, although the Court has shown that a consensus exists on a particular subject - Turkey has the highest electoral threshold within the Council of Europe member states which usually stood 5\%; it still did not find a violation of Convention. ${ }^{159}$

Despite its defects, the dynamic interpretation and consensus approach ensure that the Convention is a living instrument. This means that certain acts which were considered in the past as compatible with Convention rights may be classified differently in present day or in the future. Because, "the increasingly high standard being required in the area of the protection of human rights and fundamental liberties correspondingly and inevitably requires greater firmness in assessing breaches of the fundamental values of democratic societies." 160 Thus, living instrument doctrine

154 Paul Mahoney, "Comparative Method in Judgments of the European Court of Human Rights: Reference Back to National Law", The Role of Comparative Law in the Emergence of European Law, Lausaanne, 14-15 Avril 2000, Schuthess, Publications of the Swiss Institute of Comparative Law, 43, Zurich, 2002, p. 143-157, 143.

155 Herbert Petzold, The Convention and the Principle of Subsidiarity, in The European System For the Protection of Human Rights, eds. Macdonald - F. Matscher - H. Petzold., 1993, Netherlands, p. 41; Eva Brems, "The Margin of Appreciation Doctrine in the Case-Law the European Court of Human Rights, Heidelberg Journal of International Law, Vol. 56, 1996, pp. 276-274, 300-304; Carozza, p. 1226-1227; Dinah Shelton, The Boundaries of Human Rights Jurisdiction in Europe, Duke of Journal of Comparative and Internatiol Law, Vol. 13, 2003, p. 134; Shelton, Subsidiarity and Human Rights Law, HRLJ, Vol. 27, 2006, No. 4, at 9-11.

156 Helfer, p.141; Benvenisti, p.851 ("In the jurisprudence of the ECHR, consensus is inversely related to the margins doctrine: the less the court is able to identify a European-wide consensus on the treatment of a particular issue, the wider the margins the court is prepared to grant to the national institutions.")

157 Carozza, p.1217-1237. As Brems put in her study, "(1)ike for margin analysis in general, the Court should elaborate a methodology for its consensus analysis, identifying criteria that play a role, in order to increase the transparency and predictability of its approach" (Eva Brems, "The Margin of Appreciation Doctrine in the Case-Law the European Court of Human Rights, Heidelberg Journal of International Law, Vol. 56, 1996, p.285).

158 Arai-Takahashi, pp. 195-196; George Letsas, "The Truth in Autonomous Concepts: How to Interpret the ECHR", European Journal of International Law, Vol. 15, No. 2, 2004, pp. 279-305, 297-305; Brauch, pp.146-147; Carozza, p. 1231

159 Yumak and Sadak v. Turkey, App. No.10226/03, Grand Chamber Judgment of 8 July 2008, paras. 61-64.

160 See, mutadis mutandis, Selmouni v. France, Application no. 25803/94, Judgment of 28 July 1999, para. 101. 
"can be used to update the application of Convention rights to reflect modern, higher expectations of member States". ${ }^{161}$ Accordingly, consensus doctrine may bring a balance between traditional non-intervention concerns and effective adjudication in electoral matters in the 21 th century world.

The second aspect of the application of dynamic interpretation and consensus approach is to make reference to international norms and case law. ${ }^{162}$ This kind of reference to international norms and case law can easily be considered natural since several provisions of the Convention, including the Preamble, make reference to international law. ${ }^{163}$ Moreover, Article 31/3 (c) of the Vienna Convention on the Law of Treaties of 1969 envisages that during interpretation any relevant rules of international law applicable in the relations between the parties shall be taken into account. ${ }^{164}$ Since supranational human rights law is an integral system, and since most of the Convention rights are also included by other major human rights instruments and there is growing jurisprudence on those rights through the activities of relevant supervisory bodies, it can fairly be suggested to use related instruments and jurisprudence in the determination of the scope of rights set forth in the ECHR. The Court has already accepted the role of Article 31/3 (c) of the Vienna Convention on the Law of Treaties of 1969 in interpreting and applying the Convention. ${ }^{165}$ Thus, it is not surprising to observe the European Court of Human Rights' continuous reference to supranational norms and case law standards. Having acknowledged international standards in abstract level, the Court has reached a general principle or formula that it "can and must take into account elements of international law other than the Convention, the interpretation of such elements by competent organs, and the practice of European States reflecting their common values". ${ }^{166}$

As a result, both national and international consensus approach may limit the effect of margin of appreciation doctrine under P1-3. Accordingly, while examining the ECtHR's judgments concerning independent candidates, it is fair to take into account of international and domestic developments on the matter which described in detail above.

\footnotetext{
161 Alastair Mowbray, "The Creativity of the European Court of Human Rights", Human Rights Law Review, Vol. 5, N.1, 2005, pp.57-79, 64 .

162 For the Court's reference to international instruments in the margin of appreciation context, see, Brems, p.286-288.

163 Articles 7/1, 15/1, 35 (former 26), Protocol No.1 Article 1.

164 See McLachan, The Principle of Systemic Integration and Article 31 (3) (c) of the Vienna Convention, 54 ICLQ 279, at 290 (2005). In his detailed study, McLachlan states that " $(\mathrm{t})$ he formulation refers to rules of international law in general. The words are apt to include all of the sources of international law, including custom, general principles, and, where applicable, other treaties" (emphasis added).

165 Loizidou v. Turkey, App. No.15318/89, GC Judgment of 18 December 1996, para. 43.

166 Demir and Baykara, App. No.34503/97, GC Judgment of 12 November 2008, para.85 (emphasis added). The Court also stated that "when it considers the object and purpose of the Convention provisions, it also takes into account the international law background to the legal question before it. Being made up of a set of rules and principles that are accepted by the vast majority of States, the common international or domestic law standards of European States reflect a reality that the Court cannot disregard when it is called upon to clarify the scope of a Convention provision that more conventional means of interpretation have not enabled it to establish with a sufficient degree of certainty." (para.76).
} 


\section{B) Critical Remarks on the Jurisprudence of the European Court of Human Rights Concerning Custom Votes}

\section{(1) Validity of the "Technical Difficulty Argument"}

Both the Turkish Constitutional Court and the majority of the ECtHR in Oran and Timurhan cases accepted the idea that there was/is technical difficulty in counting the custom votes for independent candidates.

One may wonder this technical difficulty argument can still be considered valid at the time of the application in 2007 and at the time of the deliverance of the ECtHR's judgment in 2014. In this context, one should note that technical difficulty argument was obviously "not a legal argument" in the legal sense, since it simply referred to the "technicalities" of the election process. Therefore, it is not acceptable to derive normative legal conclusions from technical difficulty argument.

From this particular perspective, the question is that whether it was appropriate for the Constitutional Court to invoke and place such a decisive role to "technical difficulties" argumentation in its judgment while assessing the compatibility of the electoral regulation with the Constitution. ${ }^{167}$ Judging on the constitutionality of a law is different than assessing such "difficulties" of the "technical arrangements" concerning the electoral issues.

Even one may suggest that such "technical difficulties" might be considered by the Constitutional Court, it is then a reasonable expectation from the angle of jurisprudential policy that convincing argumentation on this specific issue should be added into the decision. In the Constitutional Court decision, however, there was neither any explanation on the so-called technical difficulties matter, nor any evidence that the Constitutional Court sought for any expert opinion on the issue.

Indeed, both the judgments of the Turkish Constitutional Court and the European Court lack of concrete example of said technical difficulty which prevents independent candidates from enjoying custom votes. Accordingly, technical difficulty argument was/is an empty stereotyped argument which lacks any particular component.

Moreover, even assuming that the "technical difficulties" ground was appropriate, it is important to take into account the fact that the applicants in review submitted their applications to the European Court in 2007, at a time when 20 years had already been passed over the Constitutional Court's judgment given in 1987. Consequently, the competent national authorities should be in the position to overcome, if there was indeed, such "technical arrangement difficulties" in order to secure free and full electoral rights of the citizens living abroad to vote for the independent candidates and

167 Article 148 the Constitution which provides that "The Constitutional Court shall examine the Constitutionality in respect of both form and substance of laws, decrees having force of law, and the rules of Procedure of the GNAT of Turkey." 
thus to provide that independent candidates benefit from such ballots. It is actually not easy to find a rational answer to the question why the independent candidates standing for the general election, including the applicant Baskın Oran himself, should suffer from the competent authorities' inability, slowness and/or unwillingness in finding a reasonable solution to this problem. Same considerations may apply to voters' case, as the chosen system under the terms of Article 94/2 of the Election Law did not ensure the free expression of the opinion of the people in the choice of the legislature.

Furthermore, the element of time, a period of 25 years, is also important in the light of electoral technological facilities of our time. If it was really considered that the limited capacities were a determinant factor in providing a proper solution to the mentioned "technical arrangement difficulties" in late 1980's, how can one continue to argue that said reason is still valid in the 2010's?

Technical difficulty argument of the ECtHR is also not in conformity with State's positive obligations under P1-3. Both in the Oran and Timurhan cases, the ECtHR's acceptance of technical difficulty argument did not take into account of the positive obligations of States which explicitly requires States to take measures for the compatibility of electoral legislation and process with international human rights standards. In this particular context positive obligations in 2007 and/or 2014 are wider in scope than they were in 1987 (the date Turkish Constitutional Court delivered its judgment on technical difficulty argument). The ECtHR never took into account of the positive obligations doctrine under P1-3, despite the fact that the applicants obviously based their argumentation on positive obligations. ${ }^{168}$

Dissenting judges rightfully mentioned this point with reference to Venice Commission standards (Venice Commission, document CDL-AD (2011) 022, paragraphs 77-84). ${ }^{169}$ Dissenting judges have argued that it is possible to create a system that allow custom votes to be counted for independent candidates and therefore technical difficulty argument cannot be considered "insurmountable". ${ }^{170}$

\section{(2) Lack of Balance between the Right to Enjoy Custom Votes and Right to Vote for Independent Candidates at Customs and Political Stability of the Country}

Both the Turkish Constitutional Court and the majority of the ECtHR in Oran and Timurhan cases accepted an assumption that the interference with the applicants' right to enjoy customs vote and right to vote for independent candidates had been designated to ensure political stability of Turkey and stroke fair balance between those competing

\footnotetext{
168 Oran v. Turkey, App. Nos. 28881/07 \& 37920/07, Judgment of 15 April 2014, para 41 (The Applicant's Submissions).

169 European Commission for Democracy Through Law (Venice Commission), Report on Out-Of-Country Voting, Adopted by the Council for Democratic Elections at its 37th meeting (Venice, 16 June 2011) and by the Venice Commission at its 87th plenary session (Venice, 17-18 June 2011).

170 Oran v. Turkey, App. Nos. 28881/07 \& 37920/07, Judgment of 15 April 2014, para.7 of Dissenting Opinion.
} 
interests. The majority of the ECtHR thus concluded that, taking into consideration the wide margin of appreciation left to Turkey (State Party), the limitation in question could be considered objective and reasonable. The majority accepted that the "restriction" is based on the legitimate concern the legislature may have to limit the influence of citizens resident abroad in elections on issues which primarily affect persons living in the country. The majority also distinguished between political parties and independent candidates with regard to their function and possible role in the political life of a country, and therefore considered political parties primarily with respect to electoral rights. The Court implicitly has accepted that independent candidates were not worth taking into consideration in the political life.

These above arguments are the "embracement" of the Turkish Constitutional Court's judgment by the ECtHR. In addition to this "embracement", the European Court developed further arguments with a view to legitimize non-residents could only vote for political parties in the polling stations at posts. According to the majority, so called "restriction" enhances democratic pluralism as it prevents excessive and dysfunctional fragmentation of candidacies. And consequently so called "restriction" ultimately strengthens the expression of the opinion of the people in the choice of the legislature within the meaning of P1-3. As a result, the majority of the European Court found no infringement of the very essence of the right to the free expression of the opinion of the people (Timurhan Case) or the Applicant's right to stand for election (Oran Case), for the purposes of P1-3 taken alone and in conjunction with Article 14 of the Convention. ${ }^{171}$

One can hardly accept the reasoning of the ECtHR (and the Turkish Constitutional Court). It is so obvious, even at first sight, that the ECtHR decision that fair balance had been stroke is merely an assumption which was not elaborated or supported by any concrete evidence. Even one cannot able to see any general framework which draws the particular guidance of the balancing test or the factors to be taken into account in such situations. It seems that the ECtHR merely reflected general principles pertaining to P1-3. ${ }^{172}$ However, its wording still lacks concrete guidance and only consists of clichés such as the need to strike balance between competing interests and the States" "wide margin of appreciation" in electoral matters.

Moreover, the European Court admitted that the Applicants' situation was different from other cases concerning expatriate voting. ${ }^{173}$ But this admittance did not prevent it

171 Oran v. Turkey, App. Nos. 28881/07 \& 37920/07, Judgment of 15 April 2014, paras. 62-66 of the Majority Opinion; Timurhan v. Turkey, App. No.28882/07, Admissibility Decision of 16 December 2014, para. 20.

172 Oran v. Turkey, App. Nos. 28881/07 \& 37920/07, Judgment of 15 April 2014, paras.49-54, especially, 52-54.

173 Oran v. Turkey, App. Nos. 28881/07 \& 37920/07, Judgment of 15 April 2014, para.55. "The Court first of all notes that the applicant's situation differs from other cases in which it considered the inability expatriate nationals to vote in parliamentary elections from their current place of residence and whether there was an obligation on States Parties under Article 3 of the Additional Protocol, to enact legislation enabling such expatriates to exercise their voting rights from abroad (see Sitaropoulos and Giakoumopoulos [GC], cited above, § 70, and Shindler v. the United Kingdom, No. 19840/09, § 109, 7 May 2013)." 
to make analogy between these types of cases with a view to reach non-infringement judgment. ${ }^{174}$ Here one should note that in Oran and Timurhan cases, there was no issue of organizing the electoral vote around the globe for a number of potential voters. As in the case of Timurhan, the potential voters who wished to vote for non-affiliated independent candidates were present at the custom polls by the time the SEC determined.

Furthermore, again one cannot see any application of that balancing framework to the specific aspects of the present cases. The majority of the ECtHR merely referred to "wide margin of appreciation" and "political stability", and decided that the "restriction" was not excessive. The majority of the ECtHR never discussed how the applicants' claims of enjoying customs vote and to vote for independent candidates at the customs poll would harm political stability or what kind of counter interests to be given to the applicants for the purposes of balancing. Obviously, it is not easy to take the majority of ECtHR's unfounded assumption based on abstract concerns as real reasoning.

Even when the concept of "implied limitations" under P1-3 and the States Parties' wide margin of appreciation in imposing restrictions in this field are accepted, it must be recalled that the European Court has already clearly ruled that the compatibility of that aim with the principle of the rule of law and the general objectives of the Convention must be proved in the particular circumstances of the case. In examining compliance with Article 3 of Protocol No. 1, the Court has focused mainly on two criteria: whether there has been arbitrariness or a lack of proportionality, and whether the restriction has interfered with the free expression of the opinion of the people. ${ }^{175}$

Literature criticized the Court's approach to the interpretation of the right to free elections as it is cautious, which is evidenced by the wide margin of appreciation granted to the States and the weaker form of scrutiny adopted compared to the rights protected by Article 8-11 of the Convention. ${ }^{176}$

Since the ballots given at the customs will necessarily be added on to the ballots of political parties (in accordance with Article 94/2 of the Election Law), neither voters can vote for independent candidates nor the independent candidates can enjoy the ballots given at the customs. Thus, contrary to the ECtHR's interpretation, the system in question cannot be considered as "restriction" or "limitation"; it amounts to a total ban. Accordingly, the chosen system under the terms of Article 94/2 of the Election Law did not and still does not ensure the free expression of the opinion of the people in the choice of the legislature. The dissenters in the Oran judgment

\footnotetext{
174 Oran v. Turkey, App. Nos. 28881/07 \& 37920/07, Judgment of 15 April 2014, paras, 60 and 63. In fact, the majority wrongly followed the Grand Chamber's Sitaropoulos and Giakoumopoulos v. Greece judgment (App. No.42202/07, Grand Chamber Judgment of 15 March 2012). It is worth mentioning that, the First Section of the ECtHR found a violation of P1-3 in the Sitaropoulos and Giakoumopoulos v. Greece case (Judgment of 8 July 2010).

175 See, Zdanoka v. Latvia, Grand Chamber Judgment of 16 March 2006, para. 115/b-c.

176 Harris/O’Boyle/Warbrick, p.732. Also see, Golubok, p.376.
} 
believe that total ban of giving vote to the independent candidates is equal to force expatriate voters to give their votes to political parties. And this fact denies free expression of the opinion of the people in the choice of the legislature. According to the dissenters, if the legislative body of Turkey did want to decrease the effect of expatriate voters in Turkish politics, it would have found a proportionate way to limit the expatriate voters. Especially in the presence of very high electoral threshold, total ban of independent candidates to enjoy expatriate/custom votes cannot be considered as a legitimate mean for the purpose of political stability. ${ }^{177}$

The statutory blockage (total ban) lacks reasonable ground and in any case lacks proportionality. It has two aspects which result in violations, namely, the right to vote for "independent candidates" in respect of the Turkish citizens living abroad, i.e. the so-called "active" aspect of the rights under P1-3, and an individual's right to stand as a candidate for election, i.e. the so-called "passive" aspect of the rights under P1-3, in the sense that "independent candidates" consequently are deprived of their right to enjoy the ballots of a certain group of electors who actually and actively take part in the election. As the dissenters stated clearly, "If the legislature had wished to restrict the influence of voters residing outside the national territory, they would have opted for methods other than prohibiting them from voting for independent candidates, naturally with respect for the requirements of Article 3 of Protocol No. 1."178

It may be added that, with regard to the position adopted by the legislature and judiciary in Turkey, there is no evidence that Parliament has ever sought to weigh the competing interests or to assess the proportionality of a categorical exclusion of the right to vote ${ }^{179}$ for independent candidates or independent candidate's right to benefit the votes used at the customs.

In this context, it can be alleged that the decisions of the ECtHR in the Oran and Timurhan cases are in contradictory with the Grand Chamber's Yumak and Sadak ruling of 8 July 2008. In Yumak and Sadak Case, the Grand Chamber accepted the excessive nature of $10 \%$ electoral threshold. However, the Grand Chamber did not find that this excessive threshold violates P1-3, since specific political context of the elections in question provides independent candidature opportunity to recover the essence of the right to stand for elections on the basis of the possibility of independent candidates. ${ }^{180}$ It should be recalled that the Turkish Government had submitted the independent candidature opportunity as a corrective measure and a kind of safeguard for the existence of excessive $10 \%$ threshold. ${ }^{181}$ Taking into account of the increased number

\footnotetext{
177 Oran v. Turkey, App. Nos. 28881/07 \& 37920/07, Judgment of 15 April 2014, para. 7 of the Dissenting Opinion.

178 Oran v. Turkey, App. Nos. 28881/07 \& 37920/07, Judgment of 15 April 2014, para. 7 of the Dissenting Opinion.

179 O'Boyle, "Electoral Disputes and the ECHR", p.4. ("Exclusions of any groups or categories of the general population must accordingly be reconcilable with the underlying purpose of Article 3 of Protocol No.1.")

180 See, Yumak and Sadak v. Turkey, App. No.10226/03, Grand Chamber Judgment of 08 July 2008, para. 147.

181 Yumak and Sadak v. Turkey, para.133.
} 
of independent candidates in 2007 elections, the Grand Chamber consequently found that independent candidature method could not be considered ineffective in practice of the general elections held in 22 July 2007. According to the Grand Chamber in Yumak and Sadak Case, "the fact that independents were not required to reach any threshold...nevertheless, this was a make shift solution compared with the position of a candidate officially sponsored by his or her political party". ${ }^{182}$

If this statement is taken seriously, then there is a need to provide an answer to the question of compatibility of such statement with the fact that in the Oran and Timurhan cases the application of the Turkish Election Law can neither be categorized as a "limitation" nor a "restriction". The legal consequence of the implementation of said Law is reaching a degree of a "total ignorance" of the right, due to fact that Turkish citizens living abroad have not any opportunity to vote for independent candidates in the 2007 general election and thus the independent candidates had and still have no opportunity to enjoy the ballots given at the customs by such Turkish citizens.

Then unavoidable questions appear: If independent candidature method is a corrective measure and a kind of safeguard for high electoral threshold, isn't it a total ban of enjoying expatriate voters excessive measure amounting a violation of P1-3? If the independent candidate could not enjoy custom/expatriate votes and a voter could not vote for independent candidates at customs polls, then is it still possible to consider independent candidature as a safeguard or corrective measure for the excessive \%10 threshold? If the ban of enjoying expatriate voters serves democratic pluralism and strengthens the expression of the opinion of the people in the choice of the legislature and consequently does not violate P1-3 (as the majority of the Court accepted), then is it possible to legitimize the excessive $10 \%$ electoral threshold? ${ }^{183}$

It must be noted that national electoral threshold of 10\% in 2007 in Turkey is the only example among States Parties to the European Convention, since average for the other States Parties is around 5\% only. ${ }^{184}$ As the Organization for Security and Co-operation in Europe (OSCE) report of 2002 stated that, the 10\% national threshold in Turkey's electoral system apparently eliminates the possibility of regional or minority parties entering the Turkish Grand National Assembly and distorts the very purpose of a proportional system. ${ }^{185}$

On the other hand, as indicated in the EU Commission's “Turkey 2011 Progress Report" "186, "No changes were made to the electoral system. The $10 \%$ of the national

\footnotetext{
182 Yumak and Sadak v. Turkey, para.138, in fine.

183 See, also para. 7, in fine and para. 8 of Dissenting Opinion in Oran judgment.

184 Zimbron, p.18; Golubok, pp.377-378;. O'Boyle, "Electoral Disputes and the ECHR”, p.10.

185 Zimbron, p.18. (Reference: OSCE, Office for Democratic Institutions and Human Rights, Assessment Report: Republic of Turkey Parliamentary Elections, 2002.)

186 "Turkey 2011 Progress Report", Communication from the Commission to the European Parliament and the Council, Brussels, 12.10.2011, SEC(2011) 1201 final, p.8.
} 
vote required for representation in parliament, which is the highest threshold in any Council of Europe member state, remains, despite calls by political parties and civil society organizations for it to be lowered. This issue featured prominently during the election campaign." So no progress has been achieved since it was noted in the "Turkey 2007 Progress Report". ${ }^{187}$

One cannot find any explanation for this internal contradiction within the jurisprudence of the ECtHR concerning electoral rights in Turkey under P13. Majority of the ECtHR in the Oran and Timurhan cases clearly neglected the embedded role and function of independent candidature in Turkey as ruled by Grand Chamber in Yumak and Sadak case.

Lastly, majority's distinction between political parties and independent candidates with regard to their function and possible role in the political life of a country should be addressed. As put above, the majority of the ECtHR considered political parties primarily with respect to electoral rights and used this preposition to legitimatize the total ban of the right to vote for independent candidates and the independent candidate's right to enjoy votes used at customs polls. Consequently, the European Court ignores the crucial role that would be played by the independent candidates in the political arena of the State Party, where democratic political-social opposition were prevented from active participation of political life due to $10 \%$ electoral threshold.

The aforementioned arguments do not ignore the importance of political parties in political life of a nation. There is no, however, causal relationship between the importance of political parties and the prohibition of voting for independent candidates at customs. ${ }^{188}$ The European Court's approach that independent candidates are not worth taking into consideration in the political life of a country disregards the domestic electoral systems in which independent candidates have been allowed to stand apart from the political parties and the particularities of a given country in a given electoral context. In this line, majority of the ECtHR's perspective again in contradiction with the perspective of Grand Chamber in Yumak and Sadak on the importance and role of independent candidates in Turkish electoral process.

\footnotetext{
187 "Turkey 2011 Progress Report", Communication from the Commission to the European Parliament and the Council, Brussels, Brussels, 6.11.2007, SEC(2007) 1436, \{COM(2007) 663 final $\}$, pp.6-7. "Three parties crossed the 10\% threshold of the national vote required to be represented in Parliament. These were the Justice and Development Party (AKP) with 46.6\%, resulting in 341 seats, the Republican People's Party (CHP) with 20.9\% (99 seats) and the Nationalist Movement Party (MHP) which obtained 14.3\% (70 seats). 26 independent candidates were also elected. 20 of these, from the Democratic Society Party (DTP), formed their own political group. This brought the number of political groups to four. Additional parties represented in parliament are the Democratic Left Party (DSP), with 13 Members of Parliament, the Grand Unity Party (BBP) and the Freedom and Democracy Party (ÖDP) with one seat each. Nevertheless, the debate continued on reducing the 10\% threshold, which is the highest among European parliamentary systems. This issue was also brought to the European Court of Human Rights (ECtHR), which ruled in January 2007 that the threshold does not violate the right to free elections. However, it also noted that it would be desirable for the threshold to be lowered in order to ensure optimal representation, while preserving the objective of achieving stable parliamentary majorities." (emphasis added).

188 Oran v. Turkey, App. Nos. 28881/07 \& 37920/07, Judgment of 15 April 2014, para. 7 of the Dissenting Opinion.
} 
Moreover, the European Court's implication also neglects the role of the independent candidature in enhancing the active participation of people in political life of a country, which is one of the major problems in politics. Since political parties create their own caste systems, it is not easy to enter to political parties and/or become leading actor within political parties' internal politics. Thus, the very concept of independent candidature breaks this caste, by providing opportunity not to be affiliated with any political party.

Lastly, one can borrow other international/regional human rights supervisory bodies' jurisprudence under the doctrine of international consensus as an application of dynamic interpretation. It is significant that in Yatama the I-ACtHR while recognizing the importance of political parties, nonetheless draws attention to other ways in political participation. According to the I-ACtHR: "There is no provision in the American Convention that allows it to be established that citizens can only exercise the right to stand as candidates to elected office through a political party. The importance of political parties as essential forms of association for the development and strengthening of democracy are not discounted, but it is recognized that there are other ways in which candidates can be proposed for elected office in order to achieve the same goal, when this is pertinent and even necessary to encourage or ensure the political participation of specific groups of society" (emphasis added). ${ }^{189}$ The Inter-American Court's subsequent finding in Castaneda Gutman v. Mexico case seems to confirm the ruling in Yatama that "the system of political parties is no better than any other." 190

One can add recent jurisprudence of the African Court of Human Rights. In Tanganyika Law Society and the Legal and Human Rights Centre v. The United Republic of Tanzania, concerning categorical ban of independent candidates, the African Court held that

"Having ratified the Charter, the Respondent has an obligation to make laws in line with the intents and purposes of the Charter. Thus it is the view of the Court that whilst the said clause envisages the enactment of rules and regulations for the enjoyment of the rights enshrined therein, such rules and regulations may not be allowed to nullify the very rights and liberties they are to regulate. Wherein lies any freedom if in order to even choose a representative of one's choice one is compelled to choose only from persons sponsored by political parties, however unsuitable such persons might be. To the extent that the said provision reserves to the citizen the right to participate directly or through representatives in government, any law that requires the citizen to be part of a political party she can become a candidate is an unnecessary fetter that denies to the citizen the right of direct participation, and amounts to a violation" (emphasis added).

\footnotetext{
189 The IACtHR, Case of Yatama v. Nicaragua, Judgment of 23 June 2005, (Preliminary Objections, Merits, Reparations and Costs), Series C No.127, para.215.

190 Torres, p.606 (with reference to I-ACtHR, Castaneda Gutman v. Mexico, Judgment of 6 August 2008, (Preliminary Objections, Merits, Reparations and Costs), Series C No.184, para.159).
} 
The African Court also stated that the respondent failed "to show that the restrictions on the exercise of the right to participate freely in the government of the country by prohibiting independent candidates falls within the permissible restrictions set out in Article 27/2 of the Charter. In any event, the restriction on the exercise of the right through the prohibition on independent candidacy is not proportionate" (para.107/2). ${ }^{191}$

Of course, legal problems in the judgments of the I-ACtHR and the African Court of Human Rights concerning independent candidates are not identical to the Oran and Timurhan cases before the European Court, and therefore one may raise objections to their precedential value. Moreover, I-ACtHR explicitly stated in in Castaneda Gutman v. Mexico case that "both systems, one built on the exclusive basis of political parties, and the other that also allows independent candidacies can be compatible with the Convention." ${ }^{192}$ However, the actual affect in Oran and Timurhan cases amounts to total statutory ban since the ballots given at the customs will necessarily be added on to the ballots of political parties (in accordance with Article 94/2 of the Election Law), neither voters can vote for independent candidates nor the independent candidates can enjoy the ballots given at the customs. As a result, the system chosen under the terms of Article 94/2 of the Turkish Election Law does not ensure the free expression of the opinion of the people in the choice of the legislature. Thus, Turkish citizens living abroad have no other options if they wish to vote for independent candidates in customs. Turkish citizens living abroad can only vote for political parties in customs, there is no other alternative to them. Accordingly, preventing independent candidates to enjoy votes used at customs poll does not only impair his/her rights but also the rights of potential voters, with the results that denying him/her access to ballot in turn denies the group effective representation. The total ban of the right to vote for independent candidates and the independent candidate's right to enjoy votes used at customs polls affected negatively the broadest and freest expression of the will of the electorate, which implies grave consequences for democracy. ${ }^{193}$

\section{C) Critical Remarks on the Jurisprudence of the European Court of Human Rights concerning Exclusion of Independent Candidates to Make Political Propaganda in State-Run Media}

\section{(1) Are Political Parties and Independent Candidates in a Comparable Situation?}

The majority of the ECtHR in the Oran case pursued its distinction between political parties and independent candidates and decided that these two cannot be considered

\footnotetext{
191 ACtHPR, Tanganyika Law Society and the Legal and Human Rights Centre v. Tanzania and Reverend Christopher R. Mtikila v. Tanzania, App. Nos. 009/11 and 011/11, Judgment of 14 June 2013, para. 109.

192 Castaneda Gutman v. Mexico, Judgment of 6 August 2008, (Preliminary Objections, Merits, Reparations and Costs), Series C No.184, para.204.

193 See, mutadis mutandis, the IACtHR Case of Yatama v. Nicaragua, para.226. Also see Johns, p.50.
} 
to be in a comparable situation, this time for the purposes of electoral campaign. According to the majority, it was in the nature of the role they played in the sense that political parties, the only bodies which could come to power, had the capacity to influence the whole of the regime in their countries. An independent candidate did not have the capacity to exercise the same influence as a political party. ${ }^{194}$

As put just above, these assumptions of the majority of the European Court are not only excessively abstract and without substance but also entirely ignore the political and legal realities of Turkey. These assumptions seem also superficial as convincingly demonstrated in the separate opinion. Dissenters rightly emphasized that even an independent candidate, if elected, may play important role in the political life of the country. Dissenters have argued that with regard to electoral campaign, political parties and the independent candidates were/are in a comparable situation for the purposes of Article 14 of the Convention. ${ }^{195}$

Independent candidates can easily play important role in the political life of a nation. Firstly, according to Article 80 of the Turkish Constitution all elected candidates irrespective of they are affiliated to any political party or independent represent whole country and whole nation not their own constituencies or constituents. ${ }^{196}$ In the light of the clear wording of Article 80 of the Turkish Constitution, it is not easy to agree and accept the majority of the ECtHR's assumption regarding independent candidates. If and when elected, independent candidates become in a position to directly influence the whole of the regime in Turkey, as the political developments following the 2007 elections already demonstrated.

It is not unknown political reality of Turkey that independent candidates who managed to be elected would subsequently formed and joined a political party or joined a one already existed but did not run at the election because of high electoral threshold, and consequently able to form a group within the Parliament. It is also well known that they played a critical and historical political role which has a direct and full influence upon the political debates, agenda and developments of the country.

Consequently, in the specific circumstances of the 2007 parliamentary elections, neither national nor international circles may convincingly argue that independent candidates in the election period and independent MPs within the parliament after the election have no crucial function in the political life of the country.

\footnotetext{
94 Oran v. Turkey, App. Nos. 28881/07 \& 37920/07, Judgment of 15 April 2014, para. 73.

195 Oran v. Turkey, App. Nos. 28881/07 \& 37920/07, Judgment of 15 April 2014, para.14 of the Separate Opinion.

196 In English: "Members of the Grand National Assembly of Turkey shall not represent their own constituencies or constituents, but the Nation as a whole".
} 
In fact, the Grand Chamber of the European Court has already accepted the argument that specific political context of 2007 elections in question provided independent candidature opportunity to recover the essence of the right to stand for elections on the basis of the possibility of independent candidates against the existence of the excessive $\% 10$ electoral threshold. Since I have dealt with the effects of Yumak and Sadak ruling in the context of custom votes, I shall refrain from re-indicating all my ideas concerning the contradiction between the Grand Chamber's ruling in Yumak and Sadak case and the majority judgment of the Second Section in Oran case. But for the closure of the argument, I just remind that as the Grand Chamber has considered independent candidature institution as an effective remedy or safeguard, it is impossible to accept the assumption of the majority of the Second Section that an independent candidate did not have the capacity to exercise considerable influence in the political life of nation.

As a conclusion, assumption of the majority of the Second Section in the Oran case clearly contradicts with the role of independent candidature in Turkey as ruled by Grand Chamber in Yumak and Sadak case and therefore political parties and independent candidates are in a comparable situation for the purposes of electoral campaign $^{197}$, where excessive electoral threshold exists.

\section{(2) Grounds for Excluding Independent Candidates to Make Political Campaign in State Run Media and State Positive Obligations}

Having found that independent candidates and political parties were/are in a comparable situation at least for the purposes of 2007 elections held in Turkey in question, it is time to consider whether there are compelling, objective and reasonable grounds for preventing the independent candidate making political propaganda and campaign in state run media (radio and television channels of the TRT).

The right to stand as a candidate in an election, which is guaranteed by P1-3 and is inherent in the concept of a truly democratic regime, would be illusory if an independent candidate be prevented from making propaganda speeches at the state run media while political parties which stand for the election are entitled to do so. ${ }^{198}$ Only reasonable, legitimate and compelling grounds which political pluralism or fundamental democratic principles necessitate, could justify such a regulation that may prevent independent candidates to benefit from propaganda speeches at the state run media.

The very facts of the case (independent candidate phenomenon in 2007 parliamentary elections and \% 10 electoral threshold) indicates there are not

\footnotetext{
197 For the analyses of electoral discrimination jurisprudence of the ECtHR see, Raulston, pp. 684-687.

198 See, mutadis mutandis, Podkolzina v. Latvia, App. No.46726/99, Judgment of 09 April 2002, para. 35; Melnychenko v Ukraine, App. No.17707/02, Judgment of 19 October 2004, para. 59; Lykourezos v. Greece, App. No.33554/03, Judgment of 15 June 2006, para.56; Russian Conservative Party of Entrepreneurs and others v. Russia, App. Nos.55066/00 and 55638/00, Judgment of 11 January 2007, para. 50.
} 
reasonable, legitimate and compelling grounds for excluding independent candidates to make political campaign in state run media. Here I again confine myself to refer to the above writings concerning the Grand Chamber's acknowledgment of the importance of the independent candidacy in 2007 elections in Yuman and Sadak case.

Moreover, Article 52/II of the Election Law provides every political party to make political propaganda and campaign in state run media, even under certain circumstances legislation in question gives additional propaganda time to some particular parties as stated in the SEC's Decision No.600 of 26 June 2007. Therefore, being independent candidate and being political party is not the reasonable and objective criteria to determine who is going to use state run media, as the dissenters emphasize in their separate opinion. ${ }^{199}$

It may further be noted that Turkish legislation and decisions of the SEC also created a discriminative position between the independent candidates and political parties with regard to state's duty to provide equitable political competition conditions. The European Court clearly held that "the State's participation in the campaign costs of the registered candidates, aimed at promoting equality among the contestants, should also not be overlooked." ${ }^{200}$

The duty of "providing equitable competition conditions" has two dimensions. On the one hand, it is the duty of the State not to harm or impede the candidate's right to stand for a "fair election" and, on the other hand, not to place the "independent candidate" under disproportionate difficulties which in turn becomes an illegitimate and unfair advantage for the individual candidates affiliated to a particular political party.

In this particular context, it is necessary to combine the positive obligations of the States under Article 10 of the Convention and free and fair elections with a view to amplify weak positive obligations under P1-3 because of the "unquestionable" wide margin of appreciation of States. In the political sphere, the State is under the obligation to hold free elections at reasonable intervals by secret ballot under conditions which will ensure the free expression of the opinion of the people in the choice of the legislature. Such expression is inconceivable without the participation of a plurality of political parties and individual candidates representing the different shades of opinion to be found within a country's population. By relaying this range of opinion, not only within political institutions but also with the help of the staterun media - at all levels of social life, individual candidates (and of course political parties) make an irreplaceable contribution to political debate, which is at the very core of the concept of a democratic society. While freedom of expression is important for every person, it is especially so for an individual candidate who is willing to

\footnotetext{
199 Oran v. Turkey, App. Nos. 28881/07 \& 37920/07, Judgment of 15 April 2014, para.14 of the Separate Opinion.

200 Sukhovetskyy v. Ukraine, App. No.13716/02, Judgment of 28 March 2006, para. 61.
} 
become a representative of the whole nation in accordance with Article 80 of the Turkish Constitution. ${ }^{201}$

In Manole and Others v. Moldova Judgment of 17 September 2009, the ECtHR once again reaffirms that the duty on the state to ensure that the public has access through television and radio to impartial and accurate information and a range of opinion and comment, reflecting inter alia the diversity of political outlook within the country. ${ }^{202}$ According to the European Court, in States where public service broadcasting networks were created, "domestic law and practice must guarantee that the system provides a pluralistic service. Particularly where private stations are still too weak to offer a genuine alternative and the public or State organisation is therefore the sole or the dominant broadcaster within a country or region, it is indispensable for the proper functioning of democracy that it transmits impartial, independent and balanced news, information and comment and in addition provides a forum for public discussion in which as broad a spectrum as possible of views and opinions can be expressed." ${ }^{203}$ (emphasis added).

Contrary to the conclusion reached by the Court in Oran case, the same Court found that the respondent State had not complied with its positive obligations under Article 10 of the Convention in Manole ruling. The European Court described the State as the ultimate guarantor of the principle of pluralism and stated that in performing that role the State is under an obligation to adopt positive measures to "organize" democratic elections "under conditions which will ensure the free expression of the opinion of the people in the choice of the legislature." ${ }^{204}$ The right to stand as a candidate in an election would be illusory if the individual candidate cannot enjoy the advantages of state run media. ${ }^{205}$ Referring to the hallmarks of a "democratic society", the Court has attached particular importance to pluralism, tolerance and broadmindedness. According to the ECtHR, democracy does not simply mean that the views of the majority must always prevail. ${ }^{206}$

The aforementioned requirement cannot be achieved without the participation of a plurality of not only political parties but also independent candidates, especially in a country where excessive 10\% electoral threshold applies. As a result, a balance must be achieved which ensures the fair and proper treatment of all competing actors in an election and avoids any abuse of a dominant position of political parties against

\footnotetext{
201 See, mutadis mutandis, Christian Democratic People's Party v. Moldova, App. No.28793/02, Judgment of 14 February 2006, paras. 66-67.

202 Manole and Others v. Moldova, App. No.13936/02, Judgment of 17 September 2009, para. 100.

203 Id., para. 101.

204 Yumak and Sadak v. Turkey, para.106.

205 The applicant also emphasized that at the time when the applicant stood for the election, i.e. in 2007, "political propaganda by use of internet" was not recognized. This possibility was recognized for the first time recently by the promulgation of Law No.5980 of 08 April 2010 which added a new Article 55/B to the Law No.298 on Elections (Oran v. Turkey, para.42The Applicant's Submissions part). The European Court did not pursue this allegation in its reasoning.

206 See, Baczkowski and Others v. Poland, App. No.1543/06, Judgment of 03 May 2007, para.63.
} 
individual candidates. ${ }^{207}$ By ignoring to set a requisite balance, the majority of the European Court leaves room for abuse of dominant position that political parties hold.

\section{(3) Relevancy of Using Other Means of Campaign Argument}

The majority in Oran case relied on the assumption that the applicant had not been barred from using other means of campaign. According to the majority, "the applicant was not prevented from conducting a campaign in the electoral district in which he was standing as an independent. While he did not have access to election broadcasts on TRT - whose TV channels and radio stations broadcast nationwide - he was not prevented from using all the other available methods of electioneering, which were accessible to all the unaffiliated independent candidates at the material time." Here the ECtHR makes a distinction between independent candidates whose affiliated to any political party and non-affiliated independent candidates and found that "the measure criticised by the applicant in his capacity as an unaffiliated independent candidate was based on objective and reasonable justification."208

There are some reasons indicated that this assumption may be not well founded with regard to the nature and the role of state run media in electoral progress: Firstly, one should take into account of the fact that that State-run media in Turkey (TRT) has more than fourteen television channels and nine radio channels. Some of these channels also broadcast in different languages such as Kurdish and Arabic, languages spoken by a considerable number of the citizens in Turkey.

Secondly, the citizens' right to be informed and to form an opinion within the meaning of Article 10 of the Convention cannot be disregarded, especially during an election process. As it is the case in the Oran case, there may be instances that the citizens' right to be informed and to form an opinion by itself and independently is subjected to an unlawful interference.

In fact, the European Court cited following international instruments on the issue in question: 209

The Committee of Ministers, in its Recommendation No. R (99) 15 on "Measures Concerning Media Coverage of Election Campaigns" of 09 September 1999 states, inter alia, that "the public service broadcasters have a particular responsibility in ensuring in their programmes a fair and thorough coverage of elections which may include the granting of free airtime to political parties and candidates". With regard to free airtime for political parties/candidates on public broadcast media, the Committee of Ministers emphasizes that

\footnotetext{
207 See, mutatis mutandis, Chassagnou and Others v. France, App. Nos.25088/94, 28331/95 and 28443/95, Grand Chamber Judgment of 29 April 1999, para. 112.

208 Oran v. Turkey, App. Nos. 28881/07 \& 37920/07, Judgment of 15 April 2014, para.76. See also Council of Europe, Guide on Article 3 of Protocol No. 1 to the European Convention on Human Rights - Right to Free Elections, Updated on 31 August 2017, Council of Europe, 2017, p.21, para.84.

209 Oran v. Turkey, App. Nos. 28881/07 \& 37920/07, Judgment of 15 April 2014, paras.26-29.
} 
"wherever such airtime is granted, this should be done in a fair and non-discriminatory manner, on the basis of transparent and objective criteria."

The Venice Commission in the Code of Good Practice in Electoral Matters of 2002 states the following: "Equality of opportunity must be guaranteed for political parties and candidates alike. This entails a neutral attitude by State authorities, in particular with regard to: (i) the election campaign; (ii) coverage by media, in particular by the publicly owned media" and "Equality of opportunity applies in particular to radio and television airtime, public funds and other forms of backing." (emphasis added).

One may add the OSCE Copenhagen Document (adopted on 29 June 1990), provides the following: "(7.7) ensure that law and public policy work to permit political campaigning to be conducted in a fair and free atmosphere in which neither administrative action, violence nor intimidation bars the parties and the candidates from freely presenting their views and qualifications, or prevents the voters from learning and discussing them..." and "(7.8) provide that no legal or administrative obstacle stands in the way of unimpeded access to media on a non-discriminatory basis for all political groupings and individuals wishing to participate in the electoral process." (emphasis added).

However, the majority of the Court did not take into account of these documents in its reasoning and decided that there was no discrimination with regard to exclusion of non-affiliated independent candidates from enjoying airtime on state run media for electioneering purposes.

This conclusion of the majority also is not in line with the jurisprudential standards in which the Court itself has already acknowledged that the audio-visual media have a more immediate and powerful effect than the print media. ${ }^{210}$ The aforementioned dictum of the European Court also enlightens the fact that why all propaganda means and methods (namely, propaganda speech at the state run media, on the one hand, and distributing leaflets, propaganda flags or making propaganda speeches in closed areas, on the other hand) cannot be treated equally.

Apart from the fact that an individual applicant in the Oran case suffers from economic restrains for making political propaganda in general, the possibility to benefit from airtime on state run media for electioneering purposes is crucial on the part of individual candidates.

The state running mass media are essential to the conduct of democratic elections. A free and fair election is not only about casting a vote in proper conditions, but also about having adequate information on parties, policies, candidates and the election process itself so that voters can make an informed choice. A democratic election with no opportunity to make propaganda in state running media would be contradictory with the standards of the Convention.

210 See, mutadis mutandis, TV Vest As \& Rogaland Pensjonistparti v. Norway, App. No.21132/05, Judgment of 11 December 2008, para. 60 and para. 76. 
The categorical disqualification of non-affiliated independent candidates from making propaganda speeches at the TRT (public corporate body) but granting this opportunity only to the political parties cannot be considered as compatible with the requirement of neutrality of the State authorities and their positive obligation to enable voters to know the lists and candidates standing for election, especially in a country where $10 \%$ electoral threshold applies. ${ }^{211}$ According to Article 133 of the Constitution and Article 8 of the Law on Radio and Television of Turkey ${ }^{212}$, the TRT is an impartial public corporate body. However, independent candidates are not only prevented from making propaganda speeches at the TRT but also deprived from an opportunity for political advertisements. It follows that under these circumstances independent candidates were forced to compete by their political adversaries under apparent discriminative and unfair political competition conditions, which lacked any legitimate ground.

Distinguishing between the candidates who stand for the election in such a manner and without basing it on any exceptional circumstances, such as where necessitated by a greater public interest, can only result in an "arbitrary distinction" between competing political actors.

Propaganda speeches at the State-run television, the TRT, actually became the most effective way for individual candidates to get their message across to the public through that type of medium. By being denied this possibility under the law, the individual candidate's position was at a disadvantage, compared to that of political parties which had granted not only public funding but also to make political propaganda at the TRT free of charge. ${ }^{213}$

As a result, the legislation in question and the decisions of the SEC based on the said legislation could have affected the decision-making process of electors in a discriminatory manner as the non-affiliated independent candidates have been categorically excluded from enjoying airtime on state run media for electioneering purposes on the mere ground that they were an "non-affiliated independent candidate" while the political parties were able to do so.

\section{V) Conclusion}

Jurisprudential standards pertaining to the right to vote and the right to stand for election (P1-3) are weak due to the unwillingness of the ECtHR to infiltrate domestic policies of the state parties. But once labeled P1-3 as enshrining two rights in 1987, namely the right to vote and the right to stand for election, the ECtHR's judicial

\footnotetext{
211 Again it is possible to refer to Yumak and Sadak ruling of Grand Chamber (Yumak and Sadak v. Turkey, para.147).

212 Law on Radio and Television of Turkey (Türkiye Radyo ve Televizyon Kanunu), Law No.2954 of 11/11/1983, (Official Gazette, 14/11/1983, no.18221).

213 See, mutatis mutandis, TV Vest As \& Rogaland Pensjonistparti v. Norway, App. No.21132/05, Judgment of 11 December 2008, para. 73.
} 
self-restraint on electoral matters cannot be considered as legitimate. Said judicial self-restraint is not inconformity with the Courts interpretive tools, such as principle of effectiveness and living instrument doctrine (based on dynamic interpretation).

One may further question appropriateness of the European Court's approach in recognizing that State Parties have an almost unlimited margin of appreciation. Such kind of margin of appreciation prevents the Court to make clear and concrete assessments about the real situations before it. I think that such an excessive margin of appreciation is not compatible with the principle of effectiveness, which has become an interpretive means in order to provide the compliance with the object and purpose of the Convention.

Looking from this perspective, the independent candidate phenomenon in Turkish general elections gains more significance due to fact that the legal requirement of $10 \%$ electoral threshold constituted a concrete barrier before the fair political participation and a pluralistic composition of the parliament. Consequently, imposing unfair restrictions on independent candidates also result in deprivation of political participation rights of political minority groups whose political opinions and expectations were voiced by such independent candidates. The electoral system operating in the 2007 elections did serve the monopolization of political power by majorities without giving an opportunity to minorities to be represented fairly and properly both at the election processes and in the composition of the parliament.

As to the identification of electoral trends, the works of Venice Commission may play considerable role in harmonizing the legal systems of the State Parties and consequently narrowing the margin of appreciation left to the States. ${ }^{214}$

The decisions of the ECtHR on independent candidates with regard to 2007 parliamentary elections held in Turkey (Judgment of Oran v. Turkey and Admissibility Decision of Timurhan v. Turkey) also failed to take into account of not only its own prior jurisprudential standards but also political and legal realities of Turkey, i.e. excessive $10 \%$ electoral threshold and phenomenon of independent candidates. ${ }^{215}$

Detailed critical remarks elaborated above with regard to the Oran and Timurhan cases indicate that the European Court's approach was not in conformity with the aims of the Convention, namely to promote and maintain the ideals and values of a democratic society, and can be considered one of the main obstacles to link democracy and human rights. In the mentioned cases, the Court itself prevents free expression of political, ideological, economic and social opinion of the people and confirms the

\footnotetext{
${ }^{214}$ On the work of Venice Commission with regard to electoral matters and its effect in the judgments of the ECtHR see Fasone/Piccirilli, pp.247-254.

215 In Mathieu-Mohin and Clerfayt v. Belgium (Judgment of 02 March 1987, Series A no. 113, para.54), the Court has stated "any electoral system must be assessed in the light of the political evolution of the country concerned."
} 
legal domestic barrier against the free choice of the legislature by failing to deal with the cases consistently.

The ECtHR also failed to use positive obligations doctrine in the Oran and Timurhan cases properly. Although in their submissions, the Applicants raised their argumentation and requested the Court to consider the standard of positive obligations, the Court simply ignored these claims and made no mention of positive obligations in its reasoning with regard to essence of the right to vote and the right to stand for election.

Also the long time-span between submitting an application and obtaining a decision of the ECtHR should be taken into account. Decisions given by the Court in many cases have no effective capacity to rectify the suffering. For example, in the cases examined in this study, in the Oran case the applicant brought the case before the ECtHR in 2007 (election year), the final decision was rendered on 15 April 2014. Similary Timurhan case was also submitted in 2007 finalized by the admissibility decision of 16 December 2014. In this long seven and the half years period there were two more elections in Turkey.

Although the Court's P1-3 judgments can be criticized that the standards stipulated by the Court in this respect are too low and the Court prefers to play a limited role, it is necessary to add that, as the President of the Court Judge Costa pointed out in 2008, the Court takes a "strict, protective approach to the essential political rights of freedom of expression, freedom of assembly and association."216

In addition to specific results, some general concluding observations on the democracy-free elections relationship can be made:

Democracy cannot be achieved merely by recognizing the right to vote and stand for election. It also requires full recognition and implementation of other relevant human rights which make it possible and practicable participation of public life of the country concerned. Consequently, the categorical exclusion of certain groups on the basis of such as belonging to minorities, sex, etc. from participation of a country's public and political life simply make democracy and the right to political participation illusory.

The end of the Cold War era does not automatically result in democratic regimes at the global scale. Although establishing formal institutions of democracy is a necessary condition for claiming human rights, there are many states which are democratic in formal-institutional terms only. ${ }^{217}$

216 Harris/O'Boyle/Warbrick, p.733. (Reference: Speech by Judge Costa, "The links between democracy and human rights under the case-law of the European Court of Human Rights", Helsinki, 5 June 2008.) Also see, Golubok, p.389; O'Boyle, "Electoral Disputes and the ECHR", p.2.

217 Tony Evans, "Introduction: power, hegemony and the universalization of human rights", in, Human Rights Fifty Years On: A Reappraisal, Tony Evans (ed.), Mancherster and New York, 1998, pp.2-23, pp.13-14. Also see, Norman Lewis, 
Suppression of the internal political opposition, systematic recourse to intimidation and violence, as well as ignoring the rights to freedom of expression, assembly and association and rights of minorities, repressing media, monitoring and/or controlling media coverage, creating a general climate of fear in the country, forming internal and external enemies categories, establishing a de facto legal impunity for public agents in their acts of abuse of power, destroying independence and impartiality of the judiciary, making legislature as an automatic approval body of the political will of the executive, diminishing or totally suspending transparency and accountability of governmental institutions and their actions; manipulating election results, excessive use of states of emergency regime by any government even when it is nationally elected should not be compatible with the principle of democratic legitimacy.

In broader perspective, since the right to democracy has often been described as the universal legitimization of Western ideas ${ }^{218}$, it may be suggested that right to democratic governance, including right to political participation, and right to peace are inseparable and inter-connected. Consequently, in addition to inter-governmental organizations' responsibility in general, the bodies of both regional and international human rights conventions in particular have to assume their historical responsibility and play an encouraging role to interpret and implement right to political participation effectively.

In the area of political participation rights the encouraging role of the supervisory bodies includes, among others, the indication of necessary domestic legal reforms even in cases where no breaches of violations have been found. In this context supervisory bodies have to enlighten the path to be pursued by addressing acceptable or at least preferable international standards on political participatory rights.

Reconsideration of, for example, wide margin of appreciation granted to national authorities might be a good starting point. Attention must also address to the fact that the problems with respect to right to political participation are not only a phenomenon of the new democracies. Legally elected anti-democratic governments should not be underestimated. In light of this to avoid firmly from balancing democracies with nondemocracies might be necessary.

The significance of international election monitoring and observation missions' reports should not be ignored. Such expert and reputable reports have to be taken more seriously in decision making process of the supervisory bodies. Mere references to

\footnotetext{
"Human rights, law and democracy in an unfreeworld", in, Human Rights Fifty Years On: A Reappraisal, Tony Evans (ed.), Manchester and New York, 1998, pp.77-104; Wheatley, pp.225-248 (The author states that "claims for human and minority rights are not made only against authoritarian governments, but also democratic ones, there must exist an implied assumption that democracy is, by itself, not capable of protecting the interests of vulnerable minorities. Moreover, as the form of government which apparently venerates the will of the majority, democracy might be considered by some as being downright hostile to the interests of individuals and minorities."); Anthony J. Langlois, "Human Rights without Democracy? A Critique of the Separationist Thesis", Human Rights Quarterly, Vol.25, No.4, November 2003, pp.990-1019.

218 Franck, "The Emerging Right to Democratic Governance", p.49; Cerna, p.290; Ezetah, p.499; Donnelly, pp.618-620.
} 
the rules of general conduct in elections prepared by either expert or political bodies should be distinguished from election missions' reports.

Moreover, the weakness and slowness of the monitoring systems of the implementation of decisions given by supervisory organs cause an additional harm both to the victim him/ herself and the credibility and effectiveness of the human rights system as a whole. If the finding of a violation necessitates a legislative changes or amendments in the State concerned, the duration of delays in the implementation of the decisions even takes longer. Such problems prevent the effective implementation of electoral standards. ${ }^{219}$

Long delays in the implementation of supervisory bodies' decisions in cases concerning political rights, right to political participation are critical not only for the countries so-called new democracies, but also for the countries having a long and established democratic practices. In the former situation, on the one hand, the establishment of a democratic system has been delayed, and on the other, the beneficiaries' enjoyment of the right to democratic governance and right to political participation has continued to be ignored. This phenomenon also introduces double and contradicting standards into the whole system and causes delays in forming and applying international democratic standards uniformly.

In the latter situation, delays in complying with the decisions of the convention organs first of all cause postponement of the remedying the violation suffered by the victims. However, the problem goes beyond that individual parameter since it also causes the denial of the right/s in question with respect to other persons who are in the same or similar condition. Moreover, reluctance in taking necessary measures in a timely manner by stable democracies provides an opportunity for the authoritarian regimes to justify, at least politically, their non-compliance policies.

The rise of popular support to authoritarian political entities and figures which may lead to hold the political power in any country is one of the obstacles that harm the obligation to comply with the decisions of the convention/covenant organs. It is the very nature of an authoritarian regime to ignore international human rights commitments as broad and long as possible. However, when the political rights in general and right to political participation in particular have been taken into account, this tendency gains strength and becomes unavoidable. It is because suppression of actual and potential political opposition and emptying the content of the right to political participation constitute essential elements for the survival of such regimes.

Consequently, in the field of the right to political participation non-compliance to the findings, rulings of the supervisory organs and systematic delays in taking necessary measures at the national level in accordance with such decisions become a serious problematic that has to be solved.

\footnotetext{
219 Binder, p.457.
} 


\section{Bibliography}

Arai-Takahashi, Yutaka; The Margin of Appreciation Doctrine and the Principle of Proportionality in the Jurisprudence of the ECHR, Antwerp-Oxford-New York, 2002.

Beckman; Ludvig; "The Right to Democracy and the Human Right to Vote: The Instrumental Argument Rejected”, Journal of Human Rights, Vol.13, No.4, 2014, pp.381-394.

Benvenisti, Eyal; "Margin of Appreciation, Consensus, and Universal Standards" New York University Journal of International Law and Politics, Vol.31, 1999, pp.843-854.

Besson, Samantha; "The human right to democracy - a moral defence with a legal nuance", in, Venice Commission, Definition and Development of Human Rights and Popular Sovereignty in Europe, Science and technique of democracy, No.49, Council of Europe Publishing, Strasbourg Cedex, December 2011, pp.47-75.

Binder, Christina; "Anything New Since the End of the Cold War? or International Law Goes Domestic: International Electoral Standards and Their Legitimacy", Anuario Espanol de Derecho Internacional, Vol.27, 2011, pp.435-463.

Brauch, Jeffrey A.; "The Margin of Appreciation and the Jurisprudence of the European Court of Human Rights: Threat to the Rule of Law", Columbia Journal of European Law, Vol.11, 2005, pp.113-150.

Brems, Eva; "The Margin of Appreciation Doctrine of the European Court of Human Rights: Accommodating Diversity Within Europe", in, Human Rights and Diversity: Area Studies Revisited, (edited by David P. Forsythe and Patrice C. McMahon), University of Nebraska Press, Lincoln and London, 2003, pp.81-110.

"The Margin of Appreciation Doctrine in the Case-Law the European Court of Human Rights, Heidelberg Journal of International Law, Vol. 56, 1996, pp. 240-314.

Buergenthal, Thomas; Norris, Robert; Shelton, Dinah; Protecting Human Rights in the Americas, Germany, 1990 (3rd ed.).

Burchill, Richard; "The Role of Democracy in the Protection of Human Rights: Lessons From the European and Inter-American Human Rights Systems", in, Human Rights and Diversity: Area Studies Revisited, (edited by David P. Forsythe and Patrice C. McMahon), Lincoln and London, 2003, pp.137-156.

Carozza, Paolo G.; "Uses and Misuses of Comparative Law in International Human Rights: Some Reflections on the Jurisprudence of the European Court of Human Rights", Notre Dame Law Review, 1998, Vol. 73, pp.1217-1237.

Cerna, Christina M.; "Universal Democracy: An International Legal Right or the Pipe Dream of the West?”, New York University Journal of International Law and Politics, Vol.27, No.2, 1995, p.289-329.

Council of Europe; Guide on Article 3 of Protocol No. 1 to the European Convention on Human Rights - Right to Free Elections, Updated on 31 August 2017, Council of Europe, 2017.

Crawford, James; "Democracy and International Law", British Yearbook of International Law, Vol.64, 1993, pp.113-133.

D'Aspremont, Jean; "Legitimacy of Governments in the Age of Democracy", International Law and Politics, Vol.38, 2006, pp.877-917.

Davidson, Scott; The Inter-American Human Rights System, Great Britain, 1997.

"The Civil and Political Rights Protected in the Inter-American Human Rights System", in, The Inter-American System of Human Rights, David J. Harris and Stephen Livingstone (eds.), Oxford, 1998, pp.213-288. 
Donnelly, Jack; "Human Rights, Democracy and Development”, Human Rights Quarterly, Vol.21, No.3, August 1999, pp.608-632.

Dothan, Shai; "Judicial Deference Allows European Consensus to Emerge", iCourts Working Paper Series, No. 22, 2015.

Emilianides, Achilles C.; "Do Minimum Age Requirements Violate the Right to Stand for Election under the European Convention on Human Rights?", European Human Rights Law Review, No.5, 2009, pp.670-683.

Evans, Tony; "Introduction: power, hegemony and the universalization of human rights", in, Human Rights Fifty Years On: A Reappraisal, Tony Evans (ed.), Manchester and New York, 1998, pp.2-23.

Ezetah, Reginald; “The Right to Democracy: A Qualitative Inquiry”, Brooklyn Journal of International Law, Vol.22, No.3, 1997, pp.495-534.

Fasone, Cristina; Piccirilli, Giovanni; "Towards a Ius Commune on Elections in Europe? The Role of the Code of Good Practice in Electoral Matters in 'Harmonizing' Electoral Rights", Election Law Journal, Vol. 16, No.2, 2017, pp.247-254.

Fitzpatrick, Joan; Human Rights in Crisis, Philadelphia, 1994.

, "States of Emergency in the Inter-American Human Rights System", in, The InterAmerican System of Human Rights, David J. Harris and Stephen Livingstone (eds.), Clarendon Press, Oxford, 1998, pp.370-394.

Fox, Gregory H.; "The Right to Political Participation in International Law", Yale Journal of International Law, Vol.17, No.2, 1992, pp.539-607.

, "Democracy, Right to, International Protection", Max Planck Encyclopedia of Public International Law, Max Planck Institute for Comparative Public Law and International Law, 2011, pp.1-13, (<www.mpepil.com>.)

Franck, Thomas; "The Emerging Right to Democratic Governance", American Journal of International Law, Vol.86, No.1, January 1992, pp.46-91.

, Fairness in International Law and Institutions, Oxford - New York, 1997.

Gearty, Conor; "Democracy and Human Rights in the European Court of Human Rights: A Critical Appraisal”, Northern Ireland Legal Quarterly, Vol.51, 2000, pp.381-396.

Gemalmaz, H. Burak; "Transformative Interpretation in International Human Rights Law: Elements of an Obligatory Judicial Dialogue Between International Judicial and Quasi-Judicial Organs", 9th World Congress of Constitutional Law, 2014, Oslo University Faculty of Law, 16-20 June 2014, Norway (<http://www.jus.uio.no/english/research/news-and-events/events/ conferences/2014/wccl-cmdc/wccl/papers/ws5/w5-gemalmaz.pdf $>$ ).

Gemalmaz, Mehmet Semih; Ulusalüstü İnsan Hakları Hukukunun Genel Teorisine Giriş (Introduction to General Theory of Supranational Human Rights Law), Cilt 1-2, İstanbul, 2012 ( $8^{\text {th }}$ ed.).

"Ulusalüstü İnsan Hakları Hukukunda Ayrımcılık Yasağı ve Eşitlik İlkesi Bağlamında ‘Özel Önlemler', 'Geçici Özel Önlemler', 'Pozitif Edim' ve 'Destekleyici Edim’”, (Special Measures, Temporary Special Measures, Positive Action, Affirmative Action in the Context of Prohibition of Discrimination and Equality Principle in Supranational Human Rights Law), Prof. Dr. Tunçer Karamustafaoğlu'na Armağan, Adalet Yayınevi, Ankara, 2010, sf.105-306.

Golubok, Sergey; "Right to Free Elections: Emerging Guarantees or Two Layers of Protection?", Netherlands Quarterly of Human Rights, Vol.27, No.3, September 2009, pp.361-390. 
Greer, Steven; The European Convention on Human Rights: Achievements, Problems and Prospects, Cambridge, 2006.

, "The Interpretation of the European Convention on Human Rights: Universal Principle or Margin of Appreciation?”, UCL Human Rights Law Review, Vol.3, 2010, pp.1-14.

Gross, Oren; Aolain, Fionnuala Ni; "From Discretion to Scrutiny: Revisiting the Application of Margin of Appreciation Doctrine in the Context of Article 15 of the European Convention on Human Rights", Human Rights Quarterly, Vol.23, No.3, August 2001, pp.625-649.

Harris, Davis J.; O'Boyle, Michael; Warbrick, Colin; Law of the European Convention on Human Rights, Oxford-New York, 2009 (second ed.).

Helfer, Laurence R.; "Consensus, Coherence and the European Convention on Human Rights", Cornell International Law Journal, Vol.26, 1993, pp.133-165.

Herndl, K.; "The Case-law of the Commission as regards the Right to Free Elections (Article 3 of Protocol 1)", in, The Birth of European Human Rights Law (Liber Amicorum Carl Aage Norgaard), Michele de Salvia - Mark E. Villiger (eds.), Baden-Baden, Germany, 1998, pp.91-99.

Heyns, Christof; "Civil and Political Rights in the African Charter", in, The African Charter on Human and Peoples' Rights: The System in Practice, 1986-2000, Malcolm D. Evans and Rachel Murray (eds.), Cambridge, 2002, pp.137-177.

Humphrey, John P.; "Political and Related Rights", in, Human Rights in International Law: Legal and Policy Issues, Theodor Meron (ed.), Oxford, 1984, pp.171-203.

Hutchinson, Michael R.; "The Margin of Appreciation Doctrine in the European Court of Human Rights”, International and Comparative Law Quarterly, Vol.48, No.3, July 1999, pp.638-650.

Johns, Alecia; "The Case for Political Candidacy as a Fundamental Human Right", Human Rights Law Review, Vol.16, 2016, pp.29-54.

Kokott, Juliane; The Burden of Proof in Comparative and International Human Rights Law, The Hague - London - Boston, 1998.

Kratochvil, Jan; "The Inflation of the Margin of Appreciation by the European Court of Human Rights", Netherlands Quarterly of Human Rights, Vol. 29/3, 2011, pp. 324-357.

Kufuor, Kofi Oteng; "The African Charter for Popular Participation in Development and Transformation: A Critical Review", Netherlands Quarterly of Human Rights, Vol.18, No.1, March 2000, pp.7-22.

Langlois, Anthony J.; "Human Rights without Democracy? A Critique of the Separationist Thesis”, Human Rights Quarterly, Vol.25, No.4, November 2003, pp.990-1019.

Lavender, Nicholas; "The Problem of the Margin of Appreciation”, European Human Rights Law Review, No.4, 1997, pp.380-390.

Lester Anthony, "Freedom of Expression”, in, The European System for the Protection of Human Rights, (edited by, Mcdonald - Matscher - Petzold), Netherlands, 1993, pp.465-491.

Letsas, George; "The Truth in Autonomous Concepts: How to Interpret the ECHR”, European Journal of International Law, Vol. 15, No. 2, 2004, pp. 279-305.

Lewis, Norman; "Human rights, law and democracy in an unfreeworld", in, Human Rights Fifty Years On: A Reappraisal, Tony Evans (ed.), Manchester and New York, 1998, pp.77-104.

Mahoney, Paul; "Judicial Activism and Judicial Self-restraint in the European Court of Human Rights: Two Sides of the Same Coin", Human Rights Law Journal, Vol.11, Parts 1-2, 1990, pp.57-88. 
, “Marvellous Richness of Diversity or Invidious Cultural Relativism?”, Human Rights Law Journal, Vol.19, No.1, April 1998, pp.1-6

, "Comparative Method in Judgments of the European Court of Human Rights:

Reference Back to National Law", The Role of Comparative Law in the Emergence of European Law, Lausaanne, 14-15 Avril 2000, Schuthess, Publications of the Swiss Institute of Comparative Law, 43, Zurich, 2002, p. 143-157

Marks, Susan; "The European Convention on Human Rights and its 'Democratic Society", British Yearbook of International Law, Vol.66, No.1, January 1996, pp.209-238.

, "What Has Become of the Emerging Right to Democratic Governance?", European Journal of International Law, Vol.22, No.2, 2011, pp.507-524.

Martin, Francisco Forrest; Schnably, Stephen J., Wilson, Richard J.; Simon Jonathan S., Tushnet, Mark V.; International Human Rights and Humanitarian Law: Treaties, Cases and Analysis, New York, 2006.

McGinnis, John O.; Somin, Ilya; "Democracy and International Human Rights Law", Notre Dame Law Review, Vol.84, No.4, 2009, pp.1739-1798.

Merrills, J.G.; The Development of International Law by the European Court of Human Rights, Manchester, 1993 ( $2^{\text {nd }}$ edition).

Meyer, Jan de; "Electoral Rights", in, The European System for the Protection of Human Rights, Macdonald et al. (eds.), Leiden, 1993, pp.553-569.

Morrison, Jr. Clovis; "Margin of Appreciation in European Human Rights Law", Human Rights Journal/Revue des Droits de l'Homme, Vol.6, 1973, pp.263-286.

Mowbray, Alastair; "The Role of the European Court of Human Rights in the Promotion of Democracy", Public Law, 1999, pp.703-725.

, The Development of Positive Obligations under the European Convention on Human Rights by the European Court of Human Rights, Hart Publishing, Oxford - Portland Oregon, 2004. , "Contemporary Aspects of the Promotion of Democracy by the European Court of Human Rights", European Public Law, Vol.20, No.3, 2014, pp.469-498.

Nowak, Manfred; U.N. Covenant on Civil and Political Rights: CCPR Commentary, Germany, 2005 ( $2^{\text {nd }}$ revised edition).

O'Boyle, Michael; “The Margin of Appreciation and Derogation under Article 15: Rituel Incantation or Principle?”, Human Rights Law Journal, Vol.19, No.1, April 1998, pp.23-29.

, "Electoral Disputes and the ECHR: An Overview", Human Rights Law Journal, Vol.30, No.1-12, 2009-2010, pp.1-12.

O'Donnell, Thomas; “The Margin of Appreciation Doctrine: Standards in the Jurisprudence of the European Court of Human Rights”, Human Rights Quarterly, Vol.4, 1982, pp.474-496.

Oraa, Jaime; Human Rights in States of Emergency in International Law, Oxford, 1992.

Organization of American States; Basic Documents Pertaining to Human Rights in the InterAmerican System (Updated to May 2001), OAS, General Secretariat, Washington, D.C., 2001.

Ovey; Clare; White, Roben C. A.; Jacobs \&. White, The European Convention on Human Rights, Oxford-New York, 2002.

Peter, Fabienne; "The Human Right to Political Participation", Journal of Ethics \& Social Philosophy, Vol.7, No.2, February 2013, pp.1-16. 
Picado, Sonia; "The Evolution of Democracy and Human Rights in Latin America: A Ten Year Perspective", Human Rights Brief, Vol.11, No.3, 2004, pp.28-31.

Pippan, Christian; "International Law, Domestic Political Orders and the 'Democratic Imperative': Has Democracy Finally Emerged as a Global Legal Entitlement?”, Jean Monnet Working Paper No 2/10, New York, 2010.

Prebensen, Soren C.; "The Margin of Appreciation and Articles 9, 10 and 11 of the Convention", Human Rights Law Journal, Vol.19, No.1, April 1998, pp.13-17.

Raulston, Elizabeth; “(Un)Justifiable?: A Comparison of Electoral Discrimination Jurisprudence at the European Court of Human Rights and the Constitutional Court of Bosnia and Herzegovina", American University International Law Review, Vol.28, No.2, 2013, pp.669-706.

Reid, Karen; A Practitioner's Guide to the European Convention on Human Rights, England, 2004 ( $2^{\text {nd }}$ ed.).

Rich, Roland; "Bringing Democracy into International Law”, Journal of Democracy, Vol.12, No.3, July 2001, pp.20-34.

Roses, Allan; “Article 21", in, The Universal Declaration of Human Rights: A Common Standard of Achievement, Gudmundur Alfredsson and Asbjorn Eide (eds.), The Hague, 1999, pp.431-451.

Rudy, Timothy D.; "A Quick Look at the Inter-American Democratic Charter of the OAS: What is it and is it 'legal'?", Syracuse Journal of International Law and Commerce, Vol.33, No.1, 2005, pp.237-248.

Saul, Matthew; “The Search for an International Legal Concept of Democracy: Lessons from the Post-Conflict Reconstruction of Sierra Leone", Melbourne Journal of International Law, Vol.12, 2012, pp.1-29.

Schabas, William A.; The European Convention on Human Rights: A Commentary, Oxford, 2015.

Shelton, Dinah; The Boundaries of Human Rights Jurisdiction in Europe, Duke of Journal of Comparative and Internatiol Law, Vol. 13, 2003, pp.95-153.

Subsidiarity and Human Rights Law, HRLJ, Vol. 27, 2006, No. 4, pp. 9-11

Schokkenbroek, Jeroen; "The Prohibition of Discrimination in Article 14 of the Convention and the Margin of Appreciation", Human Rights Law Journal, Vol.19, No.1, April 1998, pp.20-23.

--, (Revised by), "Chapter 19 - Free Elections by Secret Ballot (Article 3 of Protocol No.1)", in, Theory and Practice of the European Convention on Human Rights, Pieter van Dijk - Fried van Hoof - Arjen van Rijn - Leo Zwaak (eds.), Antwerpen - Oxford, 2006 (fourth ed.), pp.911-935.

Shany, Yuval; "Toward a General Margin of Appreciation Doctrine in International Law?", European Journal of International Law, Vol.16, No.5, 2005, pp.907-940.

Steiner, Henry; "Political Participation as a Human Right", Harvard Human Rights Yearbook, Vol.1, 1988, p.77-134.

----------, “Two Sides of the Same Coin? Democracy and International Human Rights”, Israel Law Review, Vol.41, No.3, Winter 2008, pp.445-476.

Steiner, Henry J.; Alston, Philip; International Human Rights in Context: Law, Politics, Morals, , Oxford - New York, 2000 (second ed.).

Svensson-McCarthy, Anna-Len; The International Law of Human Rights and States of Exception, The Hague, 1998.

Torres, Amaya Ubeda de; "Political Rights", in, Laurence Burgorgue-Larsen and Amaya Ubeda de Torres, The Inter-American Court of Human Rights: Case Law and Commentary, (translated by Rosalind Greenstein), Oxford - New York, 2011, pp.589-612. 
United, Nations; Human Rights: A Compilation of International Instruments, Volume 1 (First Part), United Nations, New York, 1994.

Vandewoude, Cecile; "The Rise of Self-Determination Versus the Rise of Democracy", Goettingen Journal of International Law, Vol.2, No.3, 2010, pp.981-996.

Viviani, Francesca; Right to Free Elections in the Case-Law of the European Court of Human Rights, Bachelor's Degree Thesis, Luiss Guido Carli, 2012/2013.

Wagner, Katharine A.; "Identifying and Enforcing 'Back-End' Electoral Rights in International Human Rights Law”, Michigan Journal of International Law, Vol.132, Fall 2010, pp.165-214.

Weissbrodt, David; Vega, Connie de la; International Human Rights Law: An Introduction, Philadelphia, 2007.

Wheatley, Steven; "Democracy in International Law: A European Perspective", International \& Comparative Law Quarterly, Vol.51, No.2, April 2002, pp.225-248.

Wouters, Jan; Meester, Bart De; Ryngaert, Cedric; Democracy and International Law, Leuven Interdisciplinary Research Group on International Agreements and Development, Working Paper No. 5 - June 2004, pp.1-49. (available at, <https://www.law.kuleuven.be/iir/nl/onderzoek/ wp/WPLirg5.pdf $>$; accessed on August 2017.)

Yourow, Howard Charles; The Margin of Appreciation Doctrine in the Dynamics of European Human Rights Jurisprudence, The Hague-Boston-London, 1996.

Zimbron, Ricardo; "The Unappreciated Margin: Turkish Electoral Politics Before the European Court of Human Rights", Harvard International Law Journal Online, Vol.49, November 13, 2007, pp.10-20. 
